\title{
Optimizing Phosphorus Application Rate and the Mixed Inoculation of Arbuscular Mycorrhizal Fungi and Phosphate- solubilizing Bacteria Can Improve the Phosphatase Activity and Organic Acid Content in Alfalfa Soil
}

\author{
An Xiaoxia \\ Shihezi University \\ Junying Liu \\ Shihezi University \\ Xuanshuai Liu \\ Shihezi University \\ Chunhui Ma \\ Shihezi University \\ Qianbing Zhang ( q qbz102@163.com) \\ Shihezi University https://orcid.org/0000-0003-3701-7642
}

Original article

Keywords: Alfalfa, AMF, Phosphorus application, PSB, Phosphatase activity

Posted Date: September 20th, 2021

DOI: https://doi.org/10.21203/rs.3.rs-892549/v1

License: (9) This work is licensed under a Creative Commons Attribution 4.0 International License. Read Full License 


\section{Abstract}

Alfalfa (Medicago sativa L.) is an important high-quality legume forage, and phosphorus is an important nutrient element for highquality and high-yield of alfalfa. This study assessed the effects bacteria and phosphorus $(P)$ use efficiency of alfalfa soil under different $\mathrm{P}$ applications. In this experiment, a two-factor complete randomized block design was used. Four bacterial treatments were as follows: Funneliformis mosseae $(\mathrm{Fm})$, Bacillus megaterium $(\mathrm{Bm})$, double inoculation $(\mathrm{Fm} \times \mathrm{Bm})$ and no inoculation bacteria (CK). There are four levels of phosphorus treatment, namely: phosphorus application $0\left(P_{0}\right), 50\left(P_{1}\right), 100\left(P_{2}\right), 150 \mathrm{mg} \mathrm{kg}^{-1}\left(\mathrm{P}_{3}\right)$. There were 16 treatments in total, and each treatment was repeated 6 times. The results showed that the effects of single inoculation and mixed inoculation were significantly higher than those of noninoculation $(P<0.05)$. With the increase in phosphorus application, each index increased first and then decreased. The alkaline phosphatase activity (AKP) and organic matter (SOM) content in soi lincreased with the increase of cutting times, and the content of organic matter in rhizosphere soil was higher than that in non-rhizosphere soil. Principal component analysis (PCA) shows that the top three treatments were $J_{3} P_{2}>J_{3} P_{1}>J_{3} P_{3}$. Therefore, when $\left(P_{2} O_{5}\right)$ was 100 $\mathrm{mg} \otimes \mathrm{kg}^{-1}$, the mixed inoculation of $\mathrm{Fm} \times \mathrm{Bm}$ could improve the phosphatase activity in alfalfa soil, promote the secretion of organic acids in rhizosphere soil and then improve the content of soil fertility.

\section{Key Points}

Alfalfa (Medicago sativa L.), is a perennial herb of leguminous alfalfa.

AMF and PSB are symbiotic microorganisms in nature.

Soil phosphatase can decompose lipid phosphorus and accelerate the hydrolysis process, thus increasing the content of available phosphorus in soil.

\section{Introduction}

Alfalfa (Medicago sativa L.), is a perennial herb of leguminous alfalfa. Because of its high yield, rich nutrition, huge production potential, and wide use (Zhang et al. 2020). Phosphorus is one of the most important nutrients for the normal development of plants, which are involved in the synthesis and metabolism of many important compounds in plants (Wang et al. 2018). Therefore, phosphorus has an important effect on the formation of alfalfa production performance.

Arbuscular mycorrhizal fungi (AMF) and phosphate solubilizing bacteria (PSB) are symbiotic microorganisms in nature (Kucey et al. 1983; Pandit et al. 2020). AMF can promote the uptake and utilization of phosphorus in soil by plants. The rate of P uptake by mycorrhizal plants is an important factor affecting the amount of $\mathrm{P}$ uptake by plants under a certain phosphorus concentration (Liu et al. 2019). Studies have shown that AM fungal hyphae can secrete organic acids, improve the $\mathrm{pH}$ value of the rhizosphere, and promote the transformation of organic phosphorus in soil into inorganic phosphorus that can be absorbed and utilized by plants (Bolan et al. 1991). At the same time, AMF can stimulate the secretion of plant phosphatase and enhance the activity of phosphatase, thus improving plant phosphorus nutrients (Javot et al. 2007). PSB plays an important role in the turnover and bioavailability of soil phosphorus. It can increase the dissolution and mineralization of insoluble inorganic phosphorus and organic phosphorus in soil by secreting protons, organic acids, and phosphatase (Rodriguez et al. 2007). It can be seen that the study of phosphatase activity and organic acid is an important means to study phosphate solubilizing microorganisms.

Soil phosphatase can decompose lipid phosphorus and accelerate the hydrolysis process, thus increasing the content of available phosphorus in soil (Xie et al. 2014). According to the optimal pH value of phosphatase for the dissociation of insoluble phosphate, it can be divided into hydrolytic acid phosphatase and specific alkaline phosphatase (AKP). Among them, alkaline phosphatase is a kind of specific enzyme of AMF and plant symbiosis system (Wang et al. 2014). The results showed that the acid phosphatase activity was significantly affected by PSB inoculation and phosphorus application (Gomezjurado et al. 2015). With the increase of organic acid content, insoluble phosphate in soil moved to the direction of effective dissociation (Liang et al. 2020); At the same time, due to the change of $\mathrm{pH}$ value in the soil, the phosphatase activity was indirectly affected; Organic acids can also chelate with $\mathrm{Ca}$, Al and Fe plasma to release $\mathrm{PO}_{4}{ }^{3-}$, which can effectively increase the solubility of insoluble phosphate (Saxena et al. 2016). Therefore, through the study of the two, we can reveal the partial mechanism of phosphorus solubilization in the symbiotic system of phosphorus solubilizing microorganisms and plants, which are also one of the current research hotspots. 
Interaction of AMF and PSB can enhance the ability of plants to obtain phosphorus. At present, a lot of studies mainly focus on inoculating AMF or PSB on alfalfa plants alone. However, there are relatively few studies on the effects of the interaction between AMF and PSB on the absorption of phosphorus and the secretion of phosphatase by alfalfa, as well as the relationship between various indicators, especially the effects of AMF and PSB on soil phosphatase activity. Therefore, the effects of AMF and PSB on phosphatase activity, organic acid, $\mathrm{pH}$ value, and organic matter content of alfalfa under different phosphorus application levels were studied to provide a theoretical basis for the efficient utilization of phosphorus fertilizer and the development of microbial fertilizer.

\section{Materials And Methods}

\section{Experimental materials}

In this experiment, AMF Funneliformis mosseae (Fm) was selected, which was given by the Qingdao Agricultural Mycorrhizae Research Institute of China. The inoculant was rhizosphere soil, comprising host plant root, mycorrhizal fungal spore, and ectomycorrhizal mycelium. Spore density: $25-35 \mathrm{~g}$. The host plant alfalfa variety tested was WL354HQ.

For the PSB, Bacillus megaterium (Bm) was taken from the Agricultural Culture Collection of China (ACCC, WDCM 572, 10011).

\section{Experimental design}

The experiment was conducted in a split plot based on a two-factor random block design and consisted of bacterial application and phosphorus application. Four bacterial treatments were as follows: Funneliformis mosseae (Fm), Bacillus megaterium (Bm), double inoculation $(\mathrm{Fm} \times \mathrm{Bm})$ and no inoculation bacteria (CK), respectively labeled as $J_{1}, J_{2}, J_{3}$, and $J_{0}$. There are four levels of phosphorus treatment, namely: phosphorus application $0\left(P_{0}\right), 50\left(P_{1}\right), 100\left(P_{2}\right), 150 \mathrm{mg} \varangle \mathrm{kg}^{-1}\left(\mathrm{P}_{3}\right)$, repeat 6 times for each treatment.

The experiment was conducted in the experimental base of Shihezi University $\left(44^{\circ} 18^{\prime} \mathrm{N}, 86^{\circ} 03^{\prime} \mathrm{E}\right)$ from 2019 to 2020 . The soil was sterilized in the autoclave for $2 \mathrm{~h}$ and then air-dried for standby (at $121^{\circ} \mathrm{C}$ ). A pot experiment was carried out in a nutrient bowl with an upper diameter of $23 \mathrm{~cm}$, bottom diameter of $15 \mathrm{~cm}$, and height of $16 \mathrm{~cm}$. Each pot contained $3 \mathrm{~kg}$ sterilized air-dried soil. In the treatment group $\mathrm{J}_{1}$ treatment, $\mathrm{Fm}$ was inoculated $5 \mathrm{~cm}$ below the surface of the soil in the pot, and $10 \mathrm{~g}$ of bacteria was applied in each pot to promote the colonization of alfalfa roots. In the $\mathrm{J}_{2}$ treatment group, $10 \mathrm{~mL}(\mathrm{Bm})$ bacterial solution was applied to each pot. In the $\mathrm{J}_{3}$ treatment group, alfalfa seeds were soaked for $12 \mathrm{~h}$, and then the seeds and $5 \mathrm{~mL}$ of Bm bacterial solution were planted in the flowerpot with $5 \mathrm{~g}$ (about 8500 inoculum potential units) of $\mathrm{Fm}$. In non inoculated $\mathrm{J}_{0}$ treatment group, the same amount of inactivated bacteria was added as the $J_{3}$ treatment. Select full and uniform alfalfa seeds, disinfect them with $10 \% \mathrm{H}_{2} \mathrm{O}_{2}$ for 10 min, then wash them repeatedly with distilled water, and sow them on May 1, 2019, with 10 seeds in each pot. The same amount of water was supplied every day, and then the seedlings were thinned after sowing(the growth period was three-leaf stages). Five alfalfa seedlings with uniform growth were kept in each pot, and each treatment was repeated 6 times. To keep the same daylighting, the flower pots were randomly placed. The phosphate fertilizer used was mono ammonium phosphate (containing $52 \% \mathrm{P}$ and $11 \% \mathrm{~N}$ ). To keep the same content of $\mathrm{N}$ in each treatment, urea (containing $46 \% \mathrm{~N}$ ) as added. Fertilizer is applied twice a year, on June 18 and September 19, 2019; The fertilizer will be applied on June 25 and September 27, 2020, respectively, and the fertilizer will be applied with water drop. Alfalfa is mowed twice a year, all at the initial flowering stage (5-10\%) and on August 2 and October 12 in 2019 ; It will be cut on August 12 and October 16 in 2020, and the stubble height will be $2 \mathrm{~cm}$.

The specific fertilization scheme is shown in Table 1:

\section{Soil sample collection}

The shaking method was used to collect the rhizosphere and non-rhizosphere soil. The soil directly shaking off was regarded as nonrhizosphere soil, and the soil brushed from the root with a brush was regarded as rhizosphere soil. The soil was packed in self-sealed bags and brought back to the laboratory. Transfer the soil sample to the aluminum box and dry it at $65^{\circ} \mathrm{C}$ to constant weight. Grind the dried soil sample and screen out fine soil with 100 mesh sieves for standby.

\section{Measurement index and method}


The AKP test kit was used to test the AKP in the soil, which was provided by Beijing Solarbio Technology Co., Ltd. The determination principle is as follows: AKP decomposes disodium phenyl phosphate to produce free phenol and phosphoric acid. Phenol reacts with 4-amino antipyrine in an alkaline solution and oxidizes with potassium ferricyanide to produce red quinone derivatives. The enzyme activity can be determined according to the red color (Wang et al 2016).

\section{Determination of organic acid content}

The contents of organic acids (citric acid, malic acid, oxalic acid, and acetic acid) in rhizosphere soil were determined by HPLC (Ma et al. 2020).

\section{$\mathrm{PH}$ value}

The ratio of water to soil is $5: 1$, and the $\mathrm{pH}$ meter is used for detection.

\section{Soil organic matter (SOM)}

The potassium dichromate hydration heat method was used (Liu et al. 2019).

\section{Data processing and analysis}

Excel 2010 was used for data processing. SPSS 18.0 (SPSS Inc., Chicago, IL, USA) was used for statistical analysis. Duncan's method was used for multiple comparisons after two-way ANOVA. Origin 8.5 software (OriginLab OriginPro, USA) was used for mapping. Canoco 5.0 was used for principal component analysis (PCA) of the soil microbial community. The average value of the measured data is used \pm Standard deviation.

Pearson correlation coefficient is a method to measure the degree of correlation between two variables. It is a value between 1 and -1 , in which 1 is a completely positive correlation, 0 is not a correlation, and -1 is a completely negative correlation (Chatterjee et al. 2020).

\section{Results}

\section{The AKP in the soil}

Under the same treatment, with the increase of phosphorus application, the AKP in soil increased first and then decreased (Table 2). The $\mathrm{P}_{2}$ treatment was significantly higher than other treatments under the $\mathrm{J}_{0}$ condition $(P<0.05)$, except for the first crop AKP in 2019 , and the second crop AKP in 2020 reached the highest value under the $P_{1}$ treatment. The $P_{2}$ treatment was significantly higher than other treatments under the condition of $J_{1}(P<0.05)$. Except that the AKP of the $\mathrm{P}_{1}$ treatment was significantly higher than that of the $\mathrm{P}_{0}$ treatment in $2020(P<0.05)$. The other treatments the maximum value in $\mathrm{P}_{1}$ treatment and reached the maximum value under the condition of $\mathrm{J}_{2}$, except for the first crop AKP in $2020 \mathrm{P}_{2}$ treatment was significantly higher than other treatments $(P<0.05)$. Under the $J_{3}$ condition, except for the rhizosphere soil in 2019, the $P_{2}$ and $P_{3}$ treatments were significantly higher than that of the $P_{0}$ treatment $(P<0.05)$. Under the same phosphorus application conditions, the treatment with bacteria application was significantly higher than that without bacteria application $(P<0.05)$. With the increase of mowing times, alkaline phosphatase in soil increased. In each crop, the AKP in the soil was significantly different under the $\mathrm{J}, \mathrm{P}$, and $\mathrm{J} \times \mathrm{P}$ treatments $(P<0.01)$.

\section{Soil organic acid content}

Under the same conditions, except for the oxalic acid content in 2020, the contents of malic acid, oxalic acid, and acetic acid in soil increased first and then decreased with the increase of phosphorus application (Fig. 1). Under $\mathrm{J}_{0}$ condition, except that the oxalic acid content increased gradually in 2020, the oxalic acid content of $\mathrm{P}_{2}$ treatment was significantly higher than that of $\mathrm{P}_{0}$ treatment $(P$ $<0.05)$, and there was no significant difference between $\mathrm{P}_{2}$ treatment and $\mathrm{P}_{3}$ treatment in $2019(P>0.05)$. Under the condition of $J_{1}$, the $\mathrm{P}_{3}$ treatment was significantly higher than the $\mathrm{P}_{0}$ treatment in $2019(P<0.05)$, and the $\mathrm{P}_{2}$ treatment was significantly higher than the $\mathrm{P}_{0}$ treatment in $2020(P<0.05)$. Under the $\mathrm{J}_{2}$ condition, acetic acid and malic acid reached the maximum at the $\mathrm{P}_{3}$ treatment, 
while oxalic acid and organic acid reached the maximum at the $P_{2}$ treatment. Under the $J_{3}$ condition, the $P_{3}$ treatment was significantly higher than the $\mathrm{P}_{0}$ treatment in $2019(P<0.05)$. However, in 2020, herbicide $\mathrm{P}_{2}$ and $\mathrm{P}_{3}$ treatments were significantly higher than those in the $\mathrm{P}_{0}$ treatment $(\mathrm{P}<0.05)$, and there was no significant difference between $\mathrm{P}_{2}$ treatment and $\mathrm{P}_{3}$ treatment $(P>$ 0.05). In other treatments, herbicide $P_{2}$ treatment was significantly higher than that in $\mathrm{P}_{0}$ treatment $(P<0.05)$.

\section{The $\mathrm{pH}$ value in soil}

Under the same bacteria treatment, with the increase of phosphorus application rate, the soil pH value first increased and then decreased (Table 3). Under the $\mathrm{J}_{0}$ condition, the $\mathrm{pH}$ value of the first crop rhizosphere soil had no significant difference with the increase of phosphorus application rate $(P>0.05)$, but the $\mathrm{pH}$ value of $\mathrm{P}_{2}$ and $\mathrm{P}_{3}$ treatment of non-rhizosphere soil was significantly higher than that of $\mathrm{P}_{0}$ treatment $(P<0.05)$, and there was no significant difference between $\mathrm{P}_{2}$ treatment and $\mathrm{P}_{3}$ treatment $(P>0.05)$. Under the condition of $\mathrm{J}_{1}$, there was no significant difference between the treatments of phosphorus application in $2019(P>0.05)$, but in 2020, except for the treatment of $\mathrm{P}_{2}$ and $\mathrm{P}_{3}$, the treatment of $\mathrm{P}_{1}$ was significantly higher than that of $\mathrm{P}_{0}(P<0.05)$. Under the condition of $\mathrm{J}_{2}$, the $\mathrm{pH}$ value of $\mathrm{P}_{2}$ treatment was significantly higher than that of $\mathrm{P}_{0}$ treatment in $2019(P<0.05)$, and that of $\mathrm{P}_{1}$ treatment was significantly higher than that of the $P_{0}$ treatment in $2020(P<0.05)$. Under the $J_{3}$ condition, $P_{1}$ and $P_{2}$ treatments were significantly higher than the $\mathrm{P}_{0}$ treatments in the second crop of two years $(P<0.05)$. There was no significant difference in $\mathrm{pH}$ value among treatments under the same phosphorus application $(P>0.05)$. The $\mathrm{pH}$ values of soil decreased with cutting times, and there was no significant difference between rhizosphere soil and non-rhizosphere soil. In each crop, the $\mathrm{pH}$ value was significantly different under the $\mathrm{J}, \mathrm{P}$, and $\mathrm{J} \times \mathrm{P}$ treatments $(P<0.01)$.

\section{SOM}

Under the same conditions, the content of SOM increased first and then decreased with the increase of phosphorus application (Table 4). Under $\mathrm{J}_{0}$ condition, except that the SOM content of $\mathrm{P}_{2}$ was significantly higher than that of $\mathrm{P}_{1}$ and $\mathrm{P}_{0}$ treatments $(P<0.05)$, the SOM content of $\mathrm{P}_{1}$ was significantly higher than that of $\mathrm{P}_{0}$ treatment $(P<0.05)$, and the SOM content of $\mathrm{P}_{2}$ was significantly higher than that of $\mathrm{P}_{1}$ and the $\mathrm{P}_{0}$ treatment $(P<0.05)$ in 2019. Under the condition of $J_{1}$, the SOM content of $\mathrm{P}_{1}$ was significantly higher than that of the $\mathrm{P}_{0}$ treatment in $2019(P<0.05)$, except that the SOM content of $\mathrm{P}_{2}$ was significantly higher than that of other treatments $(P<0.05)$. In 2020, the SOM content of $\mathrm{P}_{1}$ was significantly higher than that of other treatments $(P<0.05)$, and the SOM content of $P_{2}$ was significantly higher than that of $P_{0}$ treatment in other treatments $(P<0.05)$. Under the condition of $J_{2}$, the $P$ application was significantly higher than that of no $P$ application $(P<0.05)$. Except for the treatment of $\mathrm{P}_{1}$ in 2020 , the SOM content of the second rhizosphere soil was significantly higher than that of the $\mathrm{P}_{0}$ treatment $(P<0.05)$, and the SOM content of other treatments was significantly higher than that of other treatments $(P<0.05)$. Under the same $P$ application, the $J_{3}$ treatment was significantly higher than other treatments $(P<0.05)$. With the increase of mowing times, the content of SOM in rhizosphere soil was higher than that in non-rhizosphere soil. In each crop, the SOM content was significantly different under the $\mathrm{J}, \mathrm{P}$, and $\mathrm{J} \times \mathrm{P}$ treatments $(P<0.01)$.

\section{Correlation analysis of each index}

Pearson correlation analysis showed that AKP in the soil was significantly positively correlated with malic acid, oxalic acid, total organic acid and, pH value $(P<0.01)$, and significantly positively correlated with acetic acid, and SOM content $(P<0.05)($ Table 5). Malic acid was positively correlated with oxalic acid, total organic acid, and SOM $(P<0.01)$. Oxalic acid was positively correlated with acetic acid, total organic acid, and SOM $(P<0.01)$. There was a significant positive correlation between total organic acids and $\operatorname{SOM}(P<0.01)$. There was a significant positive correlation between $\mathrm{pH}$ value and SOM $(P<0.01)$.

\section{Principal component analysis (PCA)}

Based on the relevant analysis, we analyzed the main components of the total amount of alkaline phosphatase, organic matter, $\mathrm{pH}$ value in soil, malic acid, oxalic acid, acetic acid, and organic acid in the rhizosphere soil (Fig. 2). The results show that the variance contribution rate of axis 1 (Principal component 1, PC1) is 79.55\%, that of axis 2 (Principal component 1, PC2) is $15.30 \%$, and the cumulative contribution rate of PC1 and PC2 is $94.85 \%$. Therefore, it can represent the original 7 indexes, the related indexes of PC1 are $\mathrm{pH}$ value in soil, organic matter, and AKP, and the indexes related to PC2 include malic acid, oxalic acid, acetic acid, and organic 
acid. The PC1 eigenvalues were sorted as $J_{3} P_{2}>J_{3} P_{3}>J_{3} P_{1}>J_{3} P_{0}$. According to the characteristic value of each treatment on two factors and the contribution rate of the factor, the comprehensive evaluation model is $Y=0.796 Y_{1}(P C 1)+0.153 Y_{2}(P C 2)$. The greater the " $Y$ " value indicates that the treatment has the best effect on soil fertility. The top three are $J_{3} P_{2}>J_{3} P_{1}>J_{3} P_{3}$ for processing.

\section{Discussion}

\section{Effects of inoculating AMF and PSB on phosphatase activity in soil under different phosphorus applications}

Enzyme activity in the soil is not only one of the important indicators to evaluate the quality of soil microbial ecosystem (Elfstrands et al. 2007), but also an effective biological index to characterize soil microorganisms and soil fertility of alfalfa grassland (Liang et al. 2018). At the same time, the soil enzyme activity can reflect the soil biological activity and the soil biochemical reaction intensity (Tischer et al. 2014). The AKP is the key enzyme in the soil phosphorus cycle and directly affects the effectiveness of soil phosphorus (Shaw et al. 2020). Among them, alkaline phosphatase is the key enzyme in the soil phosphorus cycle, and directly affects the availability of soil phosphorus (Shaw et al. 2020). The results showed that the soil alkaline phosphatase activity increased first and then decreased with the increase of phosphorus application rate under the same bacteria treatment (Table 2). The results showed that the addition of AMF and PSB could increase the content of organic matter and nutrients in the soil, promote the metabolism of alfalfa root exudates, and make the microbial life activities more vigorous, thus improving the activities of various soil enzymes (Ghorchiani et al. 2018). In different soils, AMF has different effects on phosphatase activity in the soil and AKP. Inoculation with AMF can significantly enhance phosphatase activity in the soil and then can significantly improve its phosphorus utilization rate. For instance, inoculation with Glomus intraradices can enhance the activities of acid phosphatase and AKP of Ipomoea carnnea (Amaya-Carpio et al. 2009). Inoculating Glomus on soybean (Glycine max L.) could enhance phosphatase activity in rhizosphere soil (Abdel-Fattah et al. 2014). Mycorrhizal maize plants also enhanced phosphatase activity in soil (Wang et al., 2013). In Citrus rhizosphere soil, the activity of soil phosphatase increased significantly after inoculation with AMF (Wu et al. 2011). In rhizosphere soil, the carbon source provided by plant root exudates promotes the reproduction of phosphatase-producing microorganisms (Zhang et al. 2016), thus improving the phosphatase activity of rhizosphere soil. Therefore, inoculation plays a key role in improving phosphatase activity in the soil.

\section{Effects of inoculating AMF and PSB on organic acid content under different phosphorus applications}

Phosphorus solubilizing microorganisms mainly produce organic acids, phosphatase, and hydrogen protons, and the main way is to produce organic acids. These organic acids can chelate with calcium, aluminum, and iron plasma while reducing the $\mathrm{pH}$ value of the reaction solution, so that insoluble phosphorus can be transformed into effective phosphorus for plant use (Wen et al. 2019). The results showed that malic acid, oxalic acid, and acetic acid in rhizosphere soil increased at first and then decreased with the increase of phosphorus application rate under the same phosphorus application rate. Moreover, under the same phosphorus application rate, the amount of malic acid, oxalic acid, and acetic acid in rhizosphere soil under the same phosphorus application rate were higher than that under the no phosphorus application rate (Fig. 1). Among them, the order of organic acid content in rhizosphere soil was: acetic acid > malic acid > oxalic acid > citric acid. Citric acid was not detected in soil, which may be due to the low use efficiency of phosphorus in root exudates, and the different types of organic acids secreted by different plants to the medium are different (Oliveira et al. 2020). Meanwhile, the phosphatase activity in soil was significantly positively correlated with malic acid, oxalic acid, acetic acid, total organic acid, and pH value in the soil (Table 5), indicating that many physiological metabolic processes in plants were closely related to malic acid, citric acid, oxalic acid and acetic acid (Aoki et al. 2012). With the increase of organic acid content, the microbial population, structure, and enzyme activity in the rhizosphere soil also changed significantly, which improved the phosphorus absorption conditions, thus increased the phosphorus availability in the rhizosphere soil and enhanced the phosphorus absorption capacity of plants (Tewari et al. 2007; Li et al. 2009). Studies have shown that soybean root exudates can significantly promote the growth of rhizosphere bacteria, and the presence of bacteria can also promote the secretion of root organic acids (Saeki

et al. 1996). Meanwhile, fungi can also change the composition and content of organic acids in soil (Bavaresco et al. 2000). It can be seen that organic acids secreted by roots and microbial activity are mutually utilized and promoted.

\section{Effects of inoculating AMF and PSB on pH value and SOM content in soil under different phosphorus applications}

The $\mathrm{pH}$ value is not only an index reflecting $\mathrm{pH}$ intensity in the soil but also one of the important factors affecting phosphorus absorption in soil and utilization. The results showed that with the increase of the $\mathrm{P}$ application rate, the $\mathrm{pH}$ value in soil increased 
first and then decreased under the same bacteria treatment (Table 3). This was because the AM mycelium activity directly affected the secretion of roots, resulting in the change of $\mathrm{pH}$ value in rhizosphere soil, and indirectly stimulated the reproduction of phosphorus bacteria and fungi in the rhizosphere. Thus, the absorption, utilization, and transformation of insoluble phosphorus in soil can be greatly accelerated (Lin et al. 2016). At the same time, physical or chemical changes in the surrounding environment will directly affect the mycorrhiza, resulting in changes in the $\mathrm{pH}$ value of the rhizosphere and even the microbial flora in the rhizosphere (Wen et al. 2019). Therefore, AMF and dephosphorizing bacteria affect the organic acids secreted by roots, and then affect $\mathrm{pH}$ value in soil.

The SOM is an important indicator of soil fertility. As the largest carbon pool of the terrestrial ecosystem, it not only provides nutrients for crop growth and development but also provides energy for soil microbial decomposition activities. It can be seen that SOM content is crucial for soil respiration (Amit et al. 2020). The results showed that under the same bacteria treatment, with the increase of phosphorus application, the content of SOM increased first and then decreased, and the content of SOM in rhizosphere soil was higher than that in non-rhizosphere soil (Table 4). This may be because the organic acids and enzymes secreted by microorganisms after inoculation promote the release of soil nutrients, promote the physiological metabolism of plants and the growth and development of plants, enhance the transpiration, and promote the activation and migration of nutrients in the soil and the enrichment in the rhizosphere (Rodriguez et al. 2007).

After applying phosphate fertilizer, the interaction between AMF and PSB directly or indirectly affected the content of SOM, pH value in the soil, AKP, and organic acid. The specific performance was as follows: mixed inoculation was better than single inoculation, and single inoculation was better than non-inoculation (Fig. 2). The main reason is that the inoculated plants can absorb more $\mathrm{NH}_{4}{ }^{+}$than the non-inoculated plants, the cells can assimilate ammonia, and the $\mathrm{H}^{+}$exudates, which reduces the pH value, thus affecting the bioavailability of insoluble phosphorus in minerals (Matse et al. 2020). Due to the adsorption of cation and anion in soil solution, the $\mathrm{pH}$ value of rhizosphere soil is different, which changes the plant availability of phosphorus adsorption (Wan et al. 2019). At the same time, organic acids secreted by roots, as nutrients of microorganisms, can stimulate the growth and reproduction of acid phosphatase-producing microorganisms in organic fertilizer, and then improve the acid phosphatase content in rhizosphere soil (Giles et al. 2018).

In conclusion, the present study showed that the appropriate phosphorus application and inoculation with AMF and PSB could significantly promoted fertility in the soil field of alfalfa. The AKP in the soil, organic acid, pH value, and content of SOM increased first and then decreased with the increase of phosphorus application under the same bacteria treatment. The order of organic acid content in rhizosphere soil was acetic acid $>$ malic acid $>$ oxalic acid $>$ citric acid. The results showed that the optimum phosphorus application rate $\left(\mathrm{P}_{2} \mathrm{O}_{5}, 100 \mathrm{mg} \varangle \mathrm{kg}^{-1}\right)$ and the mixed inoculation of AMF (Fm) and PSB (Bm) could increase the phosphatase activity in alfalfa soil, promote the secretion of organic acids in rhizosphere soil, and then increase the content of SOM in alfalfa soil and improve soil fertility.

\section{Abbreviations}

AMF: Arbuscular mycorrhizal fungi;

AKP: Alkaline phosphatase activity;

Bm: Bacillus megaterium;

Fm: Funneliformis mosseae;

PSB: Phosphate solubilizing bacteria;

P: Phosphorus;

SOM: Soil organic matter.

\section{Declarations}


Not applicable.

\section{Consent for publication}

Not applicable.

\section{Availability of data and materials}

Please contact the authors for all requests.

\section{Competing interest}

The authors declare that they have no competing interests.

\section{Funding}

This research were funded by the National Natural Science Foundation of China (Grant no. 32001400, 31660693), the Fok Ying Tung Education Foundation of China (Grant no. 171099), the China Postdoctoral Science Foundation (Grant no. 2018T111120, 2017M613252), the Science and Technology Innovation Key Talent Project of Xinjiang Production and Construction Corps (2021BC034), the Youth Innovation Talent Cultivation Program of Shihezi University (Grant no. CXRC201605) and the China Agriculture Research System of MOF and MARA.

\section{Authors'contributions}

Q-B $Z$ and $J-Y L$ designed the study. J-Y $L$ interpreted the results. $X-X \quad A, J-Y L$, and $X-S L$ performed the experiments. $X-X$ A and J-Y $L$ participated in writing the manuscript: $\mathrm{W}-\mathrm{H} \mathrm{L}$ and $\mathrm{C}-\mathrm{H}$ M supervised the study. All authors read and approved the final manuscript for publication.

\section{Acknowledgments}

The authors would like to acknowledge the College of Animal Science \& Technology, Shihezi University, for supporting our study.

\section{Author details}

College of Animal Science \& Technology, Shihezi University, Shihezi, 832003, Xinjiang, China.

\section{References}

Abdel-Fattah GM, Asrar AA, Al-Amri SM, Abdel-Salam EM (2014) Influence of arbuscular mycorrhiza and phosphorus fertilization on the gas exchange, growth and phosphatase activity of soybean (Glycine max L.) plants. Photosynthetica 52: 581-588.

https://doi.org/10.1007/s11099-014-0067-0

Amaya-carpio L, Davies FT, Fox T, He C (2009) Arbuscular mycorrhizal fungi and organic fertilizer influence photosynthesis, root phosphatase activity, nutrition, and growth of Ipomoea carnea ssp. fistulosa. Photosynthetica 47: 1-10.

https://doi.org/10.1007/s11099-009-0003-x

Amit K, Krishna DG, Salil T, Salil T, Jai P, Rahul A, Narendra K, Parmanand K, Hukum S, Rajesh K (2020) Carbon mineralization and inorganic nitrogen pools under Terminalia chebula Retz.-Based agroforestry system in Himalayan foothills, India. Forest Sci 66: 634643. https://doi.org/10.1093/forsci/fxaa012

Aoki M, Fujii K, Kitayama K (2012) Environmental control of root exudation of low-molecular weight organic acids in tropical rainforests. Ecosystems 15: 1194-1203. https://doi.org/10.1007/s10021-012-9575-6

Bavaresco L, Colla R, Fogher C (2000) Different responses to root infection with endophytic microorganisms of Vitis vinifera L. cv. Pinot blanc grown on calcareous soil. J Plant Nutr 23: 1107-1116. https://doi.org/10.1080/01904160009382085 
Bolan NS (1991) A critical review on the role of mycorrhizal fungi in the uptake of phosphorus by plants. Plant Soil 134: 189-207. https://doi.org/10.1007/BF00012037

Chatterjee S (2020) A new coefficient of correlation. J Am Stat Assoc 20: 1-26. https://doi.org/10.1080/01621459.2020.1758115

Elfstrands, Hedlund K, Mrtensson A (2007) Soil enzyme activities, microbial community composition and function after 47 years of continuous green manuring. Appl soil Ecol 35: 610-621. https://doi.org/10.1016/j.apsoil.2006.09.011

Ghorchiani M, Etesami H, Alikhani HA (2018) Improvement of growth and yield of maize under water stress by co-inoculating an arbuscular mycorrhizal fungus and a plant growth promoting rhizobacterium together with phosphate fertilizers. Agr Ecosyst Environ 258: 59-70. https://doi.org/10.1016/j.agee.2018.02.016

Giles CD, Richardson AE, Cade-Menun BJ, Mezeli MM, Brown LK, Menezes-Blackburn D, Darch T, Blackwell, Martin SA, Shand CA, Stutter MI (2018) Phosphorus acquisition by citrate-and phytase-exuding Nicotiana tabacum plant mixtures depends on soil phosphorus availability and root intermingling. Physiol Plantarum 163: 356-371. https://doi.org/10.1111/ppl.12718

Gomezjurado MG, Abreu LD, Marra LM, Pfenning LH, De SMFM (2015) Phosphate solubilization by several genera of saprophytic fungi and its influence on corn and cowpea growth. J Plant Nutr 38: 675-686. https://doi.org/10.1080/01904167.2014.934480

Javot H, Pumplin N, Harrison MJ (2007) Phosphate in the arbuscular mycorrhizal symbiosis: transport properties and regulatory roles. Plant Cell and Environ 30: 310-322. https://doi.org/10.1111/j.1365-3040.2006.01617.x

Kucey RT (1983) Phosphate-solubilizing bacteria and fungi in various cultivated and virgin Alberta soils. Can J Soil Sci 63: 671-678. https://doi.org/10.4141/cjss83-068

Li SC, Ning T, Huan XJ, Yang LT, Li Q, Smith BR (2009) Changes in organic acid metabolism differ between roots and leaves of Citrus grandis in response to phosphorus and aluminum. J Plant Physiol 166: 2023-2034. https://doi.org/10.1016/j.jplph.2009.06.010

Liang GP, Wu HJ, Houssou AA, Cai DX, Wu XP (2018) Soil respiration, glomalin content, and enzymatic activity response to straw application in a wheat-maize rotation system. J Soil Sediment 18: 697-707. https://doi.org/10.1007/s11368-017-1817-y

Liang JL, Liu J, Jia P, Yang TT, Li JT (2020) Novel phosphate-solubilizing bacteria enhance soil phosphorus cycling following ecological restoration of land degraded by mining. The ISME J 14: 1-14. https://doi.org/10.1038/s41396-020-0632-4

Lin Z, Xu M G, Yu L, Zhang F S, Hodge A, Gu F (2016) Carbon and phosphorus exchange may enable cooperation between an arbuscular mycorrhizal fungus and a phosphate-solubilizing bacterium. New Phytol 210: 1022-1032.

https://doi.org/10.1111/nph.13838

Liu B, Schieber J, Mastalerz M, Teng J (2019) Organic matter content and type variation in the sequence stratigraphic context of the Upper Devonian New Albany Shale, Illinois Basin. Sediment Geol 383: 101-120. https://doi.org/10.1016/j.sedgeo.2019.02.004

Liu MH, Che YY, Wang LQ, Zhao ZJ, Zhang YC, Wei LL, Xiao Y (2019) Rice straw biochar and phosphorus inputs have more positive effects on the yield and nutrient uptake of Lolium multiflorum than arbuscular mycorrhizal fungi in acidic Cd-contaminated soils. Chemosphere 235: 32-39. https://doi.org/10.1016/j.chemosphere.2019.06.160

Ma H, Li XD, Wei MY, Zeng GQ, Xu H (2020) Elucidation of the mechanisms into effects of organic acids on soil fertility, cadmium speciation and ecotoxicity in contaminated soil. Chemosphere 239: 1-16. https://doi.org/10.1016/j.chemosphere.2019.124706

Matse DT, Huang CH, Huang YM, Yen MY (2020) Nitrogen uptake and growth of white clover inoculated with indigenous and exotic Rhizobium strains. J Plant Nutr 43: 1-15. https://doi.org/10.1080/01904167.2020.1758134

Oliveira I, Lúcia M, Simeone F, Guimares CCD, Sousa SMD (2020) Sorgoleone concentration influences mycorrhizal colonization in sorghum. Mycorrhiza 31: 259-264. https://doi.org/10.1007/s00572-020-01006-1

Pandit A, Adholeya A, Cahill D, Brau L, Kochar M (2020) Microbial biofilms in nature: unlocking their potential for agricultural applications. J Appl Microbiol 129: 199-211. https://doi.org/10.1111/jam.14609

Page 9/17 
Rodríguez H, Fraga R, Gonzalez T, Bashan Y (2007) Genetics of phosphate solubilization and its potentiant applications for improving plant growth-promotiong bacteria. Plant Soil 287: 15-21. https://doi.org/10.1007/s11104-006-9056-9

Sachay JE, Wallace RL, Johns MA (1991) Phosphate stress response in hydroponically grown maize. Plant Soil 132: 85-90. https://doi.org/10.1007/BF00011015

Saeki Y, Yamakawa T, Ikeda M, Ikeda M, Ishizuka JJ (1996) Effects of root exudates of $\mathrm{Rj}_{2} \mathrm{Rj}_{3}$ - and $\mathrm{Rj}_{4}$ - genotype soybeans on growth and chemotaxis of Bradyrhizobium japonicum. Soil Sci Plant Nutr 42: 413-417. https://doi.org/10.1080/00380768.1996.10415114

Saxena J, Rawat J, Sanwal P (2016) Enhancement of growth and yield of Glycine max plants with inoculation of phosphate solubilizing fungus Aspergillus niger K7 and biochar amendment in soil. Communi Soil Sci Plan 47: 2334-2347. https://doi.org/10.1080/00103624.2016.1243708

Shaw AN, Cleveland CC (2020) The effects of temperature on soil phosphorus availability and phosphatase enzyme activities: a cross-ecosystem study from the tropics to the Arctic. Biogeochemistry 151: 113-125. https://doi.org/10.1007/s10533-020-00710-6

Soureshjani HK, Nezami A, Kafi M, Tadayon M (2019) Responses of two common bean (Phaseolus vulgaris L.) genotypes to deficit irrigation. Agr Water Manage 213: 270-279. https://doi.org/10.1016/j.agwat.2018.09.038

Tewari RK, Kumar P, Sharma PN (2007) Oxidative stress and antioxidant responses in young leaves of mulberry plants grown under nitrogen, phosphorus or potassium deficiency. J Integr Plant Biol 49: 313-322. https://doi.org/10.1111/j.1744-7909.2007.00358.x

Tischer A, Blagodatskaya E, Hamer U (2014) Extracellular enzyme activities in a tropical mountain rainforest region of southern Ecuador affected by low soil P status and land-use change. Appl Soil Ecol 74: 1-11. https://doi.org/10.1016/j.apsoil.2013.09.007

Wan WJ, Tan JD, Wang Y, Qin Y, He HM, Wu HQ, Zuo WL, He DL (2019) Responses of the rhizosphere bacterial community in acidic crop soil to pH: Changes in diversity, composition, interaction, and function. Sci Total Environ 700: 134-148.

https://doi.org/10.1016/j.scitotenv.2019.134418

Wang F, Jiang RF, Kertesz MA, Zhang F, Feng G (2013) Arbuscular mycorrhizal fungal hyphae $m$ ediating acidification can promote phytate mineralization in the hyphosphere of maize (Zea mays L.). Soil Biol Biochem 65: 69-74.

https://doi.org/10.1016/j.soilbio.2013.05.010

Wang Q, Bao YY, Liu XW, Du GX (2014) Spatio-temporal dynamics of arbuscular mycorrhizal fungi associated with glomalin-related soil protein and soil enzymes in different managed semiarid steppes. Mycorrhiza 24: 525-538. https://doi.org/10.1007/s00572-0140572-9

Wang SY, Jian X, Wan LL, Zhou ZJ, Wang ZC, Song CL, Zhou YY, Cao XY (2018) Mutual dependence of nitrogen and phosphorus as key nutrient elements: one facilitates dolichospermum flos-aquae to overcome the limitations of the other. Environ Sci Technol 52: 5653-5661. https://doi.org/10.1021/acs.est.7b04992

Wang ZQ, Li YB, Tan XP, He WX, Wei GH (2016) Effect of arsenate contamination on free, immobilized and soil alkaline phosphatases: activity, kinetics and thermodynamics. Eur J Soil Sci 68: 126-135. https://doi.org/0.1111/ejss.12397

Wen ZH, Li HB, Shen Q, Tang XM, Shen J (2019) Trade-offs among root morphology, exudation and mycorrhizal symbioses for phosphorus-acquisition strategies of 16 crop species. New Phytol 223: 882-895. https://doi.org/10.1111/nph.15833

Wu QS, Zou YN, He XH (2011) Differences of hyphal and soil phosphatase activities in drought-stressed mycorrhizal trifoliate orange (Poncirus trifoliata) seedlings. Sci Hortic-Amsterdam 129: 294-298. https://doi.org/10.1016/j.scienta.2011.03.051

Xie XY, Weng BS, Cai BP, Dong YR, Yan CL (2014) Effects of arbuscular mycorrhizal inoculation and phosphorus supply on the growth and nutrient uptake of Kandelia obovata (Sheue, Liu and Yong) seedlings in autoclaved soil. Appl Soil Ecol 75: 162-171.

https://doi.org/10.1016/j.apsoil.2013.11.009

Zhang L, Xu MG, Liu Y, Zhang FS, Hodge A, Gu F (2016) Carbon and phosphorus exchange may enable cooperation between an arbuscular mycorrhizal fungus and a phosphate-solubilizing bacterium. New Phytol 210: 1022-1032.

Page $10 / 17$ 
https://doi.org/10.1111/nph.13838

Zhang QB, Liu JY, Liu XS, Li SY, Sun YL, Lu WH, Ma CH (2020) Optimizing water and phosphorus management to improve hay yield and water and phosphorus-use efficiency in alfalfa under drip irrigation. Food Sci Nutr, 2020, 8: 2406-

2418. https://doi.org/10.1002/fsn3.1530

\section{Tables}

Table 1 Fertilizer application scheme

\begin{tabular}{|c|c|c|c|c|c|}
\hline Number & Treatments & $\begin{array}{l}\mathrm{NH}_{4} \mathrm{H}_{2} \mathrm{PO}_{4} \\
\text { (mg/pot) } \\
\text { (Containing } \mathrm{N} 12.2 \% \text { ) }\end{array}$ & $\begin{array}{l}\mathrm{CN}_{2} \mathrm{H}_{4} \mathrm{O} \\
\text { (mg/pot) } \\
\text { (Containing } \mathrm{N} 46 \% \text { ) }\end{array}$ & $\begin{array}{l}\text { Funneliformis mosseae } \\
\text { (g/pot) }\end{array}$ & $\begin{array}{l}\text { Bacillus megaterium } \\
\text { (mL/pot) }\end{array}$ \\
\hline 1 & $\mathrm{~J}_{0} \mathrm{P}_{0}$ & 0 & 105.3 & 0 & 0 \\
\hline 2 & $\mathrm{~J}_{0} \mathrm{P}_{1}$ & 35.1 & 72.9 & 0 & 0 \\
\hline 3 & $\mathrm{~J}_{0} \mathrm{P}_{2}$ & 72.9 & 35.1 & 0 & 0 \\
\hline 4 & $\mathrm{~J}_{0} \mathrm{P}_{3}$ & 105.3 & 0 & 0 & 0 \\
\hline 5 & $J_{1} P_{0}$ & 0 & 105.3 & 10 & 0 \\
\hline 6 & $\mathrm{~J}_{1} \mathrm{P}_{1}$ & 35.1 & 72.9 & 10 & 0 \\
\hline 7 & $\mathrm{~J}_{1} \mathrm{P}_{2}$ & 72.9 & 35.1 & 10 & 0 \\
\hline 8 & $\mathrm{~J}_{1} \mathrm{P}_{3}$ & 105.3 & 0 & 10 & 0 \\
\hline 9 & $\mathrm{~J}_{2} \mathrm{P}_{0}$ & 0 & 105.3 & 0 & 10 \\
\hline 10 & $\mathrm{~J}_{2} \mathrm{P}_{1}$ & 35.1 & 72.9 & 0 & 10 \\
\hline 11 & $\mathrm{~J}_{2} \mathrm{P}_{2}$ & 72.9 & 35.1 & 0 & 10 \\
\hline 12 & $\mathrm{~J}_{2} \mathrm{P}_{3}$ & 105.3 & 0 & 0 & 10 \\
\hline 13 & $J_{3} P_{0}$ & 0 & 105.3 & 5 & 5 \\
\hline 14 & $\mathrm{~J}_{3} \mathrm{P}_{1}$ & 35.1 & 72.9 & 5 & 5 \\
\hline 15 & $\mathrm{~J}_{3} \mathrm{P}_{2}$ & 72.9 & 35.1 & 5 & 5 \\
\hline 16 & $\mathrm{~J}_{3} \mathrm{P}_{3}$ & 105.3 & 0 & 5 & 5 \\
\hline
\end{tabular}

Note: $P_{0}, P_{1}, P_{2}$, and $P_{3}$ represent $0 \mathrm{mg} \cdot \mathrm{kg}^{-1}, 50 \mathrm{mg} \cdot \mathrm{kg}^{-1}, 100 \mathrm{mg} \cdot \mathrm{kg}^{-1}$, and $150 \mathrm{mg} \mathrm{P} \mathrm{kg}{ }^{-1}$, respectively. $J_{0}, J_{1}, J_{2}$, and $J_{3}$ represent $\mathrm{CK}, \mathrm{Fm}, \mathrm{Bm}$, and $\mathrm{Fm} \times \mathrm{Bm}$, respectively.

Table 2 Alkaline phosphatase activity in rhizosphere soil and non-rhizosphere soil under different treatments $\left(U \cdot g^{-1}\right)$ 


\begin{tabular}{|c|c|c|c|c|c|c|c|c|}
\hline \multirow[t]{2}{*}{ Treatments } & \multicolumn{2}{|c|}{$\begin{array}{l}\text { Rhizosphere soil AKP in } \\
2019\end{array}$} & \multicolumn{2}{|c|}{$\begin{array}{l}\text { Non-rhizosphere soil AKP } \\
\text { in } 2019\end{array}$} & \multicolumn{2}{|c|}{$\begin{array}{l}\text { Rhizosphere soil AKP in } \\
2020\end{array}$} & \multicolumn{2}{|c|}{$\begin{array}{l}\text { Non-rhizosphere soil AKP in } \\
2020\end{array}$} \\
\hline & First cut & $\begin{array}{l}\text { Second } \\
\text { cut }\end{array}$ & First cut & Second cut & First cut & $\begin{array}{l}\text { Second } \\
\text { cut }\end{array}$ & First cut & Second cut \\
\hline $\mathrm{J}_{0} \mathrm{P}_{0}$ & $\begin{array}{l}2.76 \pm 0.04 \\
C_{c}\end{array}$ & $\begin{array}{l}6.03 \pm 0.09 \\
C d\end{array}$ & $\begin{array}{l}3.32 \pm 0.06 \\
\text { Cc }\end{array}$ & $\begin{array}{l}6.70 \pm 0.09 \\
\mathrm{Bb}\end{array}$ & $\begin{array}{l}1.84 \pm 0.01 \\
\mathrm{Cd}\end{array}$ & $\begin{array}{l}1.08 \pm 0.03 \\
\operatorname{Dd}\end{array}$ & $\begin{array}{l}1.09 \pm 0.02 \\
D c\end{array}$ & $\begin{array}{l}1.11 \pm 0.04 \\
D d\end{array}$ \\
\hline $\mathrm{J}_{0} \mathrm{P}_{1}$ & $\begin{array}{l}3.18 \pm 0.08 \\
\mathrm{Ba}\end{array}$ & $\begin{array}{l}6.62 \pm 0.08 \\
B C\end{array}$ & $\begin{array}{l}3.63 \pm 0.05 \\
\mathrm{Bb}\end{array}$ & $\begin{array}{l}7.11 \pm 0.03 \\
\mathrm{Aa}\end{array}$ & $\begin{array}{l}2.16 \pm 0.02 \\
\text { Dc }\end{array}$ & $\begin{array}{l}2.11 \pm 0.05 \\
\mathrm{Da}\end{array}$ & $\begin{array}{l}1.86 \pm 0.06 \\
\mathrm{Da}\end{array}$ & $\begin{array}{l}1.88 \pm 0.08 \\
\mathrm{Db}\end{array}$ \\
\hline $\mathrm{J}_{0} \mathrm{P}_{2}$ & $\begin{array}{l}2.93 \pm 0.04 \\
\mathrm{Bbc}\end{array}$ & $\begin{array}{l}6.81 \pm 0.03 \\
\mathrm{Ca}\end{array}$ & $\begin{array}{l}3.77 \pm 0.05 \\
\mathrm{Aa}\end{array}$ & $\begin{array}{l}7.13 \pm 0.16 \\
\mathrm{Aa}\end{array}$ & $\begin{array}{l}2.34 \pm 0.01 \\
\mathrm{Da}\end{array}$ & $\begin{array}{l}1.84 \pm 0.03 \\
\mathrm{Db}\end{array}$ & $\begin{array}{l}1.80 \pm 0.03 \\
\mathrm{Dab}\end{array}$ & $\begin{array}{l}2.59 \pm 0.07 \\
\mathrm{Da}\end{array}$ \\
\hline $\mathrm{J}_{0} \mathrm{P}_{3}$ & $\begin{array}{l}2.84 \pm 0.06 \\
\mathrm{Cb}\end{array}$ & $\begin{array}{l}6.53 \pm 0.06 \\
\mathrm{Bb}\end{array}$ & $\begin{array}{l}3.27 \pm 0.09 \\
\mathrm{BC}\end{array}$ & $\begin{array}{l}6.88 \pm 0.3 \\
\text { Bab }\end{array}$ & $\begin{array}{l}2.23 \pm 0.02 \\
\mathrm{cb}\end{array}$ & $\begin{array}{l}1.49 \pm 0.06 \\
\text { Dc }\end{array}$ & $\begin{array}{l}1.72 \pm 0.03 \\
\mathrm{Bb}\end{array}$ & $\begin{array}{l}1.65 \pm 0.01 \\
D C\end{array}$ \\
\hline $\mathrm{J}_{1} \mathrm{P}_{0}$ & $\begin{array}{l}3.18 \pm 0.02 \\
\mathrm{Ab}\end{array}$ & $\begin{array}{l}6.29 \pm 0.04 \\
\mathrm{Bb}\end{array}$ & $\begin{array}{l}3.72 \pm 0.04 \\
\mathrm{Ab}\end{array}$ & $\begin{array}{l}7.19 \pm 0.16 \\
\mathrm{Aa}\end{array}$ & $\begin{array}{l}2.17 \pm 0.07 \\
\mathrm{Bd}\end{array}$ & $\begin{array}{l}1.87 \pm 0.05 \\
\mathrm{BC}\end{array}$ & $1.51 \pm 0.05^{\mathrm{Bc}}$ & $\begin{array}{l}2.15 \pm 0.07 \\
\mathrm{Bd}\end{array}$ \\
\hline $\mathrm{J}_{1} \mathrm{P}_{1}$ & $\begin{array}{l}3.20 \pm 0.04 \\
\mathrm{Bb}\end{array}$ & $\begin{array}{l}6.32 \pm 0.12 \\
\mathrm{Cb}\end{array}$ & $\begin{array}{l}3.84 \pm 0.06 \\
\mathrm{Aa}\end{array}$ & $\begin{array}{l}7.21 \pm 0.18 \\
\mathrm{Aa}\end{array}$ & $\begin{array}{l}2.84 \pm 0.03 \\
\mathrm{Ba}\end{array}$ & $\begin{array}{l}2.97 \pm 0.03 \\
\mathrm{Bb}\end{array}$ & $\begin{array}{l}2.37 \pm 0.08 \\
\mathrm{Ca}\end{array}$ & $\begin{array}{l}5.21 \pm 0.05 \\
\mathrm{Aa}\end{array}$ \\
\hline $\mathrm{J}_{1} \mathrm{P}_{2}$ & $\begin{array}{l}3.33 \pm 0.08 \\
\mathrm{Aa}\end{array}$ & $\begin{array}{l}7.19 \pm 0.01 \\
\mathrm{Ba}\end{array}$ & $\begin{array}{l}3.35 \pm 0.08 \\
\mathrm{BC}\end{array}$ & $\begin{array}{l}7.13 \pm 0.09 \\
\mathrm{Aa}\end{array}$ & $\begin{array}{l}2.46 \pm 0.01 \\
\mathrm{Cb}\end{array}$ & $\begin{array}{l}3.72 \pm 0.06 \\
\mathrm{Ba}\end{array}$ & $\begin{array}{l}2.31 \pm 0.09 \\
\mathrm{Ca}\end{array}$ & $\begin{array}{l}3.31 \pm 0.06 \\
\mathrm{Bb}\end{array}$ \\
\hline $\mathrm{J}_{1} \mathrm{P}_{3}$ & $\begin{array}{l}3.23 \pm 0.01 \\
A b\end{array}$ & $\begin{array}{l}7.17 \pm 0.01 \\
\mathrm{Aa}\end{array}$ & $\begin{array}{l}3.34 \pm 0.05 \\
\mathrm{BC}\end{array}$ & $\begin{array}{l}6.89 \pm 0.17 \\
\mathrm{Bb}\end{array}$ & $\begin{array}{l}2.26 \pm 0.08 \\
\text { Cc }\end{array}$ & $\begin{array}{l}3.01 \pm 0.06 \\
\mathrm{Bb}\end{array}$ & $\begin{array}{l}1.79 \pm 0.04 \\
\mathrm{Bb}\end{array}$ & $\begin{array}{l}2.87 \pm 0.04 \\
\mathrm{BC}\end{array}$ \\
\hline $\mathrm{J}_{2} \mathrm{P}_{0}$ & $\begin{array}{l}3.06 \pm 0.04 \\
\mathrm{Bbc}\end{array}$ & $\begin{array}{l}6.44 \pm 0.13 \\
A B b\end{array}$ & $\begin{array}{l}3.19 \pm 0.02 \\
\mathrm{Db}\end{array}$ & $\begin{array}{l}6.91 \pm 0.15 \\
\mathrm{Ba}\end{array}$ & $\begin{array}{l}2.10 \pm 0.06 \\
\mathrm{Bd}\end{array}$ & $\begin{array}{l}1.72 \pm 0.04 \\
\text { Cc }\end{array}$ & $\begin{array}{l}1.36 \pm 0.01 \\
\mathrm{Cd}\end{array}$ & $\begin{array}{l}1.54 \pm 0.03 \\
\mathrm{Cd}\end{array}$ \\
\hline $\mathrm{J}_{2} \mathrm{P}_{1}$ & $\begin{array}{l}3.30 \pm 0.06 \\
\mathrm{Aa}\end{array}$ & $\begin{array}{l}6.63 \pm 0.08 \\
\mathrm{Ba}\end{array}$ & $\begin{array}{l}3.29 \pm 0.04 \\
\mathrm{Ca}\end{array}$ & $\begin{array}{l}7.07 \pm 0.08 \\
\mathrm{Aa}\end{array}$ & $\begin{array}{l}2.62 \pm 0.02 \\
\mathrm{Cb}\end{array}$ & $\begin{array}{l}2.32 \pm 0.03 \\
\mathrm{Ca}\end{array}$ & $\begin{array}{l}2.65 \pm 0.02 \\
\mathrm{Bb}\end{array}$ & $\begin{array}{l}3.10 \pm 0.04 \\
\mathrm{Ca}\end{array}$ \\
\hline $\mathrm{J}_{2} \mathrm{P}_{2}$ & $\begin{array}{l}3.09 \pm 0.05 \\
\mathrm{Bb}\end{array}$ & $\begin{array}{l}6.36 \pm 0.11 \\
\mathrm{Db}\end{array}$ & $\begin{array}{l}3.38 \pm 0.03 \\
\mathrm{Ba}\end{array}$ & $\begin{array}{l}6.85 \pm 0.25 \\
\mathrm{Ba}\end{array}$ & $\begin{array}{l}2.69 \pm 0.02 \\
\mathrm{Ba}\end{array}$ & $\begin{array}{l}2.29 \pm 0.02 \\
\mathrm{Ca}\end{array}$ & $\begin{array}{l}3.25 \pm 0.06 \\
\mathrm{Ba}\end{array}$ & $\begin{array}{l}2.90 \pm 0.02 \\
\mathrm{Cb}\end{array}$ \\
\hline $\mathrm{J}_{2} \mathrm{P}_{3}$ & $\begin{array}{l}2.97 \pm 0.06 \\
\mathrm{BC}\end{array}$ & $\begin{array}{l}5.22 \pm 0.10 \\
\text { Cc }\end{array}$ & $\begin{array}{l}3.31 \pm 0.06 \\
\mathrm{Ba}\end{array}$ & $\begin{array}{l}6.83 \pm 0.17 \\
\mathrm{Ba}\end{array}$ & $\begin{array}{l}2.34 \pm 0.03 \\
B C\end{array}$ & $\begin{array}{l}1.83 \pm 0.02 \\
\mathrm{Cb}\end{array}$ & $1.77 \pm 0.01^{\mathrm{Bc}}$ & $\begin{array}{l}2.21 \pm 0.08 \\
C_{c}\end{array}$ \\
\hline $\mathrm{J}_{3} \mathrm{P}_{0}$ & $\begin{array}{l}3.10 \pm 0.03 \\
A B b\end{array}$ & $\begin{array}{l}6.60 \pm 0.02 \\
A b\end{array}$ & $\begin{array}{l}3.52 \pm 0.06 \\
\mathrm{Bd}\end{array}$ & $\begin{array}{l}6.77 \pm 0.02 \\
\mathrm{Bb}\end{array}$ & $\begin{array}{l}2.26 \pm 0.01 \\
\text { Ad }\end{array}$ & $\begin{array}{l}2.27 \pm 0.06 \\
\mathrm{Ad}\end{array}$ & $\begin{array}{l}3.47 \pm 0.05 \\
\text { AC }\end{array}$ & $\begin{array}{l}3.04 \pm 0.06 \\
\text { Ad }\end{array}$ \\
\hline $\mathrm{J}_{3} \mathrm{P}_{1}$ & $\begin{array}{l}3.36 \pm 0.06 \\
\mathrm{Aa}\end{array}$ & $\begin{array}{l}6.83 \pm 0.17 \\
A c\end{array}$ & $\begin{array}{l}3.71 \pm 0.08 \\
\mathrm{BC}\end{array}$ & $\begin{array}{l}7.09 \pm 0.08 \\
\mathrm{Aa}\end{array}$ & $\begin{array}{l}2.93 \pm 0.06 \\
A b\end{array}$ & $\begin{array}{l}3.47 \pm 0.07 \\
A b\end{array}$ & $\begin{array}{l}3.51 \pm 0.11 \\
A C\end{array}$ & $\begin{array}{l}4.56 \pm 0.07 \\
\mathrm{Bb}\end{array}$ \\
\hline $\mathrm{J}_{3} \mathrm{P}_{2}$ & $\begin{array}{l}3.33 \pm 0.07 \\
\mathrm{Aa}\end{array}$ & $\begin{array}{l}7.89 \pm 0.20 \\
\mathrm{Aa}\end{array}$ & $\begin{array}{l}3.83 \pm 0.02 \\
A b\end{array}$ & $\begin{array}{l}7.25 \pm 0.04 \\
\mathrm{Aa}\end{array}$ & $\begin{array}{l}5.00 \pm 0.01 \\
\mathrm{Aa}\end{array}$ & $\begin{array}{l}3.99 \pm 0.05 \\
\mathrm{Aa}\end{array}$ & $\begin{array}{l}5.29 \pm 0.13 \\
\mathrm{Aa}\end{array}$ & $\begin{array}{l}5.43 \pm 0.05 \\
\mathrm{Aa}\end{array}$ \\
\hline $\mathrm{J}_{3} \mathrm{P}_{3}$ & $\begin{array}{l}3.14 \pm 0.09 \\
A b\end{array}$ & $\begin{array}{l}7.09 \pm 0.10 \\
A b\end{array}$ & $\begin{array}{l}4.22 \pm 0.02 \\
\mathrm{Aa}\end{array}$ & $\begin{array}{l}7.22 \pm 0.06 \\
\text { Аa }\end{array}$ & $\begin{array}{l}2.76 \pm 0.05 \\
\text { Ac }\end{array}$ & $\begin{array}{l}3.08 \pm 0.04 \\
\text { AC }\end{array}$ & $\begin{array}{l}4.92 \pm 0.06 \\
A b\end{array}$ & $\begin{array}{l}3.27 \pm 0.12 \\
A C\end{array}$ \\
\hline J & ** & ** & ** & ** & ** & ** & ** & ** \\
\hline$P$ & $\star \star$ & $\star \star$ & $\star \star *$ & $\star \star$ & ** & $\star \star *$ & $\star \star$ & $\star *$ \\
\hline$J \times P$ & $\star \star$ & $\star \star$ & $\star \star$ & $\star \star$ & $\star \star *$ & $\star \star$ & $\star \star$ & $\star \star$ \\
\hline
\end{tabular}

Note: Different capital letters in the same column indicated significant difference in different bacteria treatments under the same phosphorus application conditions $(P<0.05)$, differences small letters in the same column mean significant difference under the same bacteria application conditions $(P<0.05)$.

$P_{0}, P_{1}, P_{2}$, and $P_{3}$ represent $0 \mathrm{mg} \cdot \mathrm{kg}^{-1}, 50 \mathrm{mg} \cdot \mathrm{kg}^{-1}, 100 \mathrm{mg} \cdot \mathrm{kg}^{-1}$, and $150 \mathrm{mg} \mathrm{P} \mathrm{kg}{ }^{-1}$, respectively. $\mathrm{J}_{0}, J_{1}, J_{2}$, and $J_{3}$ represent $C K, F m$, $\mathrm{Bm}$, and $\mathrm{Fm} \times \mathrm{Bm}$, respectively. 
Table 3 The pH value of rhizosphere soil and non-rhizosphere soil under different treatments

Treatments The $\mathrm{pH}$ value of rhizosphere soil pH in 2019
The $\mathrm{pH}$ value of nonrhizosphere in 2019
The $\mathrm{pH}$ value of rhizosphere soil in 2020
The $\mathrm{pH}$ value of nonrhizosphere soil in 2020

\begin{tabular}{|c|c|c|c|c|c|c|c|c|}
\hline & First cut & Second cut & First cut & $\begin{array}{l}\text { Second } \\
\text { cut }\end{array}$ & First cut & $\begin{array}{l}\text { Second } \\
\text { cut }\end{array}$ & First cut & Second cut \\
\hline $\mathrm{J}_{0} \mathrm{P}_{0}$ & $\begin{array}{l}8.48 \pm 0.11 \\
\mathrm{Aa}\end{array}$ & $\begin{array}{l}8.24 \pm 0.06 \\
A b\end{array}$ & $\begin{array}{l}8.33 \pm 0.13 \\
\mathrm{Bb}\end{array}$ & $\begin{array}{l}8.38 \pm 0.16 \\
A c\end{array}$ & $\begin{array}{l}8.09 \pm 0.01 \\
A b\end{array}$ & $\begin{array}{l}7.87 \pm 0.04 \\
\mathrm{BC}\end{array}$ & $\begin{array}{l}8.26 \pm 0.04 \\
A b\end{array}$ & $\begin{array}{l}7.79 \pm 0.02 \\
A c\end{array}$ \\
\hline $\mathrm{J}_{0} \mathrm{P}_{1}$ & $\begin{array}{l}8.61 \pm 0.04 \\
\mathrm{Aa}\end{array}$ & $\begin{array}{l}8.40 \pm 0.11 \\
\mathrm{Aa}\end{array}$ & $\begin{array}{l}8.42 \pm 0.01 \\
\mathrm{Bb}\end{array}$ & $\begin{array}{l}8.55 \pm 0.01 \\
\mathrm{Aa}\end{array}$ & $\begin{array}{l}8.18 \pm 0.02 \\
\mathrm{Aa}\end{array}$ & $\begin{array}{l}8.16 \pm 0.04 \\
\mathrm{Aa}\end{array}$ & $\begin{array}{l}8.27 \pm 0.04 \\
A B b\end{array}$ & $\begin{array}{l}8.27 \pm 0.04 \\
\mathrm{Aa}\end{array}$ \\
\hline $\mathrm{J}_{0} \mathrm{P}_{2}$ & $\begin{array}{l}8.65 \pm 0.03 \\
\mathrm{Ba}\end{array}$ & $\begin{array}{l}8.43 \pm 0.03 \\
\mathrm{Aa}\end{array}$ & $\begin{array}{l}8.60 \pm 0.08 \\
\mathrm{Ba}\end{array}$ & $\begin{array}{l}8.42 \pm 0.01 \\
\mathrm{Bbc}\end{array}$ & $\begin{array}{l}8.19 \pm 0.01 \\
\mathrm{Aa}\end{array}$ & $\begin{array}{l}8.09 \pm 0.01 \\
\mathrm{Bb}\end{array}$ & $8.36 \pm 0.04^{\mathrm{Ba}}$ & $\begin{array}{l}7.89 \pm 0.03 \\
\mathrm{Bb}\end{array}$ \\
\hline $\mathrm{J}_{0} \mathrm{P}_{3}$ & $\begin{array}{l}8.64 \pm 0.35 \\
\mathrm{Ba}\end{array}$ & $\begin{array}{l}8.42 \pm 0.01 \\
\mathrm{Aa}\end{array}$ & $\begin{array}{l}8.70 \pm 0.35 \\
\mathrm{Aa}\end{array}$ & $\begin{array}{l}8.52 \pm 0.02 \\
\text { Aab }\end{array}$ & $\begin{array}{l}8.16 \pm 0.04 \\
\mathrm{Aa}\end{array}$ & $\begin{array}{l}8.07 \pm 0.03 \\
\mathrm{Bb}\end{array}$ & $\begin{array}{l}8.28 \pm 0.02 \\
A b\end{array}$ & $\begin{array}{l}6.39 \pm 0.01 \\
\mathrm{Bd}\end{array}$ \\
\hline$J_{1} P_{0}$ & $\begin{array}{l}8.55 \pm 0.29 \\
A b\end{array}$ & $\begin{array}{l}8.28 \pm 0.06 \\
A c\end{array}$ & $\begin{array}{l}8.33 \pm 0.01 \\
\mathrm{Bc}\end{array}$ & $\begin{array}{l}8.34 \pm 0.11 \\
A b\end{array}$ & $\begin{array}{l}7.97 \pm 0.03 \\
\mathrm{Bb}\end{array}$ & $\begin{array}{l}7.90 \pm 0.01 \\
\text { Ac }\end{array}$ & $8.19 \pm 0.01^{\mathrm{Bb}}$ & $\begin{array}{l}6.58 \pm 0.02 \\
\mathrm{Bb}\end{array}$ \\
\hline$J_{1} P_{1}$ & $\begin{array}{l}8.55 \pm 0.05 \\
A b\end{array}$ & $\begin{array}{l}8.36 \pm 0.04 \\
A B b\end{array}$ & $\begin{array}{l}8.55 \pm 0.02 \\
\mathrm{Bb}\end{array}$ & $\begin{array}{l}8.35 \pm 0.01 \\
\mathrm{Bb}\end{array}$ & $\begin{array}{l}8.08 \pm 0.02 \\
\mathrm{Ba}\end{array}$ & $\begin{array}{l}8.09 \pm 0.01 \\
\mathrm{Bb}\end{array}$ & $\begin{array}{l}8.26 \pm 0.04 \\
\mathrm{Da}\end{array}$ & $\begin{array}{l}7.88 \pm 0.02 \\
\mathrm{Ba}\end{array}$ \\
\hline$J_{1} P_{2}$ & $\begin{array}{l}8.90 \pm 0.01 \\
\mathrm{Aa}\end{array}$ & $\begin{array}{l}8.44 \pm 0.08 \\
\mathrm{Aa}\end{array}$ & $\begin{array}{l}8.92 \pm 0.02 \\
\mathrm{Aa}\end{array}$ & $\begin{array}{l}8.58 \pm 0.01 \\
\mathrm{Aa}\end{array}$ & $\begin{array}{l}8.09 \pm 0.01 \\
\mathrm{Ba}\end{array}$ & $\begin{array}{l}8.18 \pm 0.02 \\
\mathrm{Aa}\end{array}$ & $8.09 \pm 0.01 \mathrm{Ac}$ & $\begin{array}{l}6.40 \pm 0.01 \\
D c\end{array}$ \\
\hline$J_{1} P_{3}$ & $\begin{array}{l}8.89 \pm 0.08 \\
\mathrm{Aa}\end{array}$ & $\begin{array}{l}8.40 \pm 0.02 \\
\mathrm{Aab}\end{array}$ & $\begin{array}{l}8.66 \pm 0.17 \\
A b\end{array}$ & $\begin{array}{l}8.34 \pm 0.08 \\
\mathrm{Bb}\end{array}$ & $\begin{array}{l}8.06 \pm 0.04 \\
\mathrm{Ba}\end{array}$ & $\begin{array}{l}8.16 \pm 0.04 \\
\mathrm{Aa}\end{array}$ & $8.08 \pm 0.02 \mathrm{Bc}$ & $\begin{array}{l}6.38 \pm 0.02 \\
\mathrm{Bd}\end{array}$ \\
\hline $\mathrm{J}_{2} \mathrm{P}_{0}$ & $\begin{array}{l}8.57 \pm 0.05 \\
A b c\end{array}$ & $\begin{array}{l}8.13 \pm 0.01 \\
\mathrm{BC}\end{array}$ & $\begin{array}{l}8.17 \pm 0.08 \\
\mathrm{Cc}\end{array}$ & $\begin{array}{l}8.32 \pm 0.04 \\
A b\end{array}$ & $\begin{array}{l}8.09 \pm 0.01 \\
A c\end{array}$ & $\begin{array}{l}7.79 \pm 0.02 \\
\text { Cc }\end{array}$ & $\begin{array}{l}8.27 \pm 0.04 \\
A b\end{array}$ & $\begin{array}{l}6.49 \pm 0.02 \\
\mathrm{Cd}\end{array}$ \\
\hline $\mathrm{J}_{2} \mathrm{P}_{1}$ & $\begin{array}{l}8.60 \pm 0.34 \\
A b\end{array}$ & $\begin{array}{l}8.29 \pm 0.03 \\
\mathrm{Bb}\end{array}$ & $\begin{array}{l}8.49 \pm 0.02 \\
\mathrm{Ba}\end{array}$ & $\begin{array}{l}8.51 \pm 0.04 \\
\mathrm{Aa}\end{array}$ & $\begin{array}{l}8.20 \pm 0.01 \\
\mathrm{Aa}\end{array}$ & $\begin{array}{l}8.16 \pm 0.04 \\
\mathrm{Aa}\end{array}$ & $\begin{array}{l}8.29 \pm 0.02 \\
\mathrm{Aa}\end{array}$ & $\begin{array}{l}7.98 \pm 0.02 \\
\mathrm{Bb}\end{array}$ \\
\hline $\mathrm{J}_{2} \mathrm{P}_{2}$ & $\begin{array}{l}8.88 \pm 0.01 \\
\mathrm{Aa}\end{array}$ & $\begin{array}{l}8.45 \pm 0.04 \\
\mathrm{Aa}\end{array}$ & $\begin{array}{l}8.35 \pm 0.15 \\
\mathrm{Cab}\end{array}$ & $\begin{array}{l}8.54 \pm 0.01 \\
\mathrm{Aa}\end{array}$ & $\begin{array}{l}8.16 \pm 0.04 \\
A b\end{array}$ & $\begin{array}{l}8.17 \pm 0.03 \\
\mathrm{Aa}\end{array}$ & $8.17 \pm 0.03 \mathrm{Cc}$ & $\begin{array}{l}8.07 \pm 0.04 \\
\mathrm{Aa}\end{array}$ \\
\hline $\mathrm{J}_{2} \mathrm{P}_{3}$ & $\begin{array}{l}8.36 \pm 0.03 \\
C c\end{array}$ & $\begin{array}{l}8.08 \pm 0.05 \\
\mathrm{BC}\end{array}$ & $\begin{array}{l}8.27 \pm 0.03 \\
\mathrm{Bbc}\end{array}$ & $\begin{array}{l}8.45 \pm 0.10 \\
\mathrm{Aa}\end{array}$ & $\begin{array}{l}8.08 \pm 0.02 \\
B c\end{array}$ & $\begin{array}{l}8.08 \pm 0.02 \\
\mathrm{Bb}\end{array}$ & $8.08 \pm 0.02^{B d}$ & $\begin{array}{l}6.69 \pm 0.01 \\
A C\end{array}$ \\
\hline $\mathrm{J}_{3} \mathrm{P}_{0}$ & $\begin{array}{l}8.62 \pm 0.35 \\
\mathrm{Aa}\end{array}$ & $\begin{array}{l}8.09 \pm 0.03 \\
\mathrm{Bb}\end{array}$ & $\begin{array}{l}8.62 \pm 0.01 \\
A b\end{array}$ & $\begin{array}{l}8.29 \pm 0.14 \\
A b\end{array}$ & $\begin{array}{l}7.87 \pm 0.03 \\
\text { Cc }\end{array}$ & $\begin{array}{l}7.59 \pm 0.01 \\
\text { Dc }\end{array}$ & $8.19 \pm 0.01^{\mathrm{Bc}}$ & $\begin{array}{l}6.47 \pm 0.03 \\
C c\end{array}$ \\
\hline $\mathrm{J}_{3} \mathrm{P}_{1}$ & $\begin{array}{l}8.64 \pm 0.06 \\
\mathrm{Aa}\end{array}$ & $\begin{array}{l}8.36 \pm 0.06 \\
\text { ABa }\end{array}$ & $\begin{array}{l}8.75 \pm 0.02 \\
\text { Aab }\end{array}$ & $\begin{array}{l}8.25 \pm 0.20 \\
\mathrm{Bb}\end{array}$ & $\begin{array}{l}8.09 \pm 0.01 \\
\mathrm{Bb}\end{array}$ & $\begin{array}{l}7.90 \pm 0.01 \\
\mathrm{Cb}\end{array}$ & $\begin{array}{l}8.27 \pm 0.04 \\
A B b\end{array}$ & $\begin{array}{l}7.97 \pm 0.03 \\
\mathrm{Ca}\end{array}$ \\
\hline $\mathrm{J}_{3} \mathrm{P}_{2}$ & $\begin{array}{l}8.65 \pm 0.06 \\
\mathrm{Ba}\end{array}$ & $\begin{array}{l}8.33 \pm 0.06 \\
\mathrm{Ba}\end{array}$ & $\begin{array}{l}8.79 \pm 0.08 \\
\mathrm{Aa}\end{array}$ & $\begin{array}{l}8.47 \pm 0.01 \\
\mathrm{ABa}\end{array}$ & $\begin{array}{l}8.16 \pm 0.04 \\
\mathrm{Aa}\end{array}$ & $\begin{array}{l}8.00 \pm 0.01 \\
\mathrm{Ca}\end{array}$ & $\begin{array}{l}8.58 \pm 0.02 \\
\mathrm{Aa}\end{array}$ & $\begin{array}{l}7.79 \pm 0.02 \\
\mathrm{Cb}\end{array}$ \\
\hline $\mathrm{J}_{3} \mathrm{P}_{3}$ & $\begin{array}{l}8.60 \pm 0.11 \\
\mathrm{Ba}\end{array}$ & $\begin{array}{l}8.00 \pm 0.15 \\
C c\end{array}$ & $\begin{array}{l}8.76 \pm 0.10 \\
\text { Aab }\end{array}$ & $\begin{array}{l}8.31 \pm 0.02 \\
\mathrm{Bb}\end{array}$ & $\begin{array}{l}8.06 \pm 0.05 \\
\mathrm{Bb}\end{array}$ & $\begin{array}{l}7.98 \pm 0.02 \\
\mathrm{Ca}\end{array}$ & $\begin{array}{l}7.98 \pm 0.02 \\
C d\end{array}$ & $\begin{array}{l}6.27 \pm 0.03 \\
\mathrm{Cd}\end{array}$ \\
\hline$J$ & $\star \star$ & $\star \star$ & $\star \star$ & ** & $\star \star$ & ** & ** & ** \\
\hline$P$ & ** & $\star \star$ & $\star \star$ & $\star \star$ & $\star \star$ & $\star *$ & $\star \star$ & ** \\
\hline$J \times P$ & $\star \star$ & $\star \star$ & $\star \star *$ & $\star \star *$ & $\star \star$ & $\star \star *$ & $\star \star$ & $\star \star *$ \\
\hline
\end{tabular}

Note: Different capital letters in the same column indicated significant difference in different bacteria treatments under the same phosphorus application conditions $(P<0.05)$, differences small letters in the same column mean significant difference under the same bacteria application conditions $(P<0.05)$. 
$P_{0}, P_{1}, P_{2}$, and $P_{3}$ represent $0 \mathrm{mg} \cdot \mathrm{kg}^{-1}, 50 \mathrm{mg} \cdot \mathrm{kg}^{-1}, 100 \mathrm{mg} \cdot \mathrm{kg}^{-1}$, and $150 \mathrm{mg} \mathrm{P} \mathrm{kg}{ }^{-1}$, respectively. $\mathrm{J}_{0}, J_{1}, J_{2}$, and $J_{3}$ represent $C K, F m$, $\mathrm{Bm}$, and $\mathrm{Fm} \times \mathrm{Bm}$, respectively.

Table 4 Organic matter content of rhizosphere soil and non-rhizosphere soil under different treatments $\left(\mathrm{mg}^{\mathrm{k} g} \mathrm{~kg}^{-1}\right)$

Treatments Organic matter content of rhizosphere soil in 2019
Organic matter content of non-rhizosphere soil in 2019

\begin{tabular}{|c|c|c|c|c|c|c|c|c|}
\hline & rhizospher & in 2019 & $\begin{array}{l}\text { non-rhizospl } \\
2019\end{array}$ & e soil in & rhizosphe & in 2020 & $\begin{array}{l}\text { non-rhizos } \\
2020\end{array}$ & re soil in \\
\hline & First cut & Second cut & First cut & Second cut & First cut & Second cut & First cut & Second cut \\
\hline $\mathrm{J}_{0} \mathrm{P}_{0}$ & $\begin{array}{l}24.31 \pm 0.33 \\
\mathrm{Cd}\end{array}$ & $\begin{array}{l}41.32 \pm 0.36 \\
\mathrm{BC}\end{array}$ & $\begin{array}{l}20.88 \pm 0.09 \\
\text { Dc }\end{array}$ & $\begin{array}{l}38.84 \pm 0.27 \\
\text { Cc }\end{array}$ & $\begin{array}{l}25.78 \pm 0.33 \\
\mathrm{Cd}\end{array}$ & $\begin{array}{l}19.18 \pm 0.12 \\
\mathrm{Bb}\end{array}$ & $\begin{array}{l}23.52 \pm 0.88 \\
\mathrm{Cb}\end{array}$ & $\begin{array}{l}16.04 \pm 0.55 \\
\text { Dd }\end{array}$ \\
\hline $\mathrm{J}_{0} \mathrm{P}_{1}$ & $\begin{array}{l}25.25 \pm 0.41 \\
\text { Cc }\end{array}$ & $\begin{array}{l}42.9 \pm 0.28 \\
\mathrm{Cab}\end{array}$ & $\begin{array}{l}22.78 \pm 0.33 \\
\mathrm{Db}\end{array}$ & $\begin{array}{l}42.64 \pm 0.69 \\
\mathrm{Cb}\end{array}$ & $\begin{array}{l}30.68 \pm 0.64 \\
\mathrm{Ba}\end{array}$ & $\begin{array}{l}20.51 \pm 0.16 \\
\mathrm{Ca}\end{array}$ & $\begin{array}{l}28.57 \pm 0.32 \\
\mathrm{Ca}\end{array}$ & $\begin{array}{l}20.07 \pm 0.69 \\
\text { Cc }\end{array}$ \\
\hline $\mathrm{J}_{0} \mathrm{P}_{2}$ & $\begin{array}{l}33.66 \pm 0.30 \\
\mathrm{Ca}\end{array}$ & $\begin{array}{l}43.53 \pm 0.52 \\
\mathrm{Da}\end{array}$ & $\begin{array}{l}23.94 \pm 0.31 \\
\mathrm{Da}\end{array}$ & $\begin{array}{l}43.69 \pm 0.69 \\
\mathrm{Ca}\end{array}$ & $\begin{array}{l}29.10 \pm 0.64 \\
\mathrm{Db}\end{array}$ & $\begin{array}{l}21.04 \pm 0.24 \\
\mathrm{Da}\end{array}$ & $\begin{array}{l}29.31 \pm 0.93 \\
\mathrm{Da}\end{array}$ & $\begin{array}{l}25.04 \pm 0.71 \\
\mathrm{Ca}\end{array}$ \\
\hline $\mathrm{J}_{0} \mathrm{P}_{3}$ & $\begin{array}{l}30.89 \pm 0.48 \\
\mathrm{Cb}\end{array}$ & $\begin{array}{l}42.32 \pm 0.95 \\
\mathrm{Cab}\end{array}$ & $\begin{array}{l}22.25 \pm 0.05 \\
\mathrm{Db}\end{array}$ & $\begin{array}{l}42.9 \pm 0.51 \\
\mathrm{Dab}\end{array}$ & $\begin{array}{l}27.62 \pm 0.84 \\
\text { Dc }\end{array}$ & $\begin{array}{l}20.88 \pm 0.18 \\
\mathrm{Ba}\end{array}$ & $\begin{array}{l}28.26 \pm 0.27 \\
\mathrm{Ca}\end{array}$ & $\begin{array}{l}22.83 \pm 0.29 \\
\mathrm{Db}\end{array}$ \\
\hline $\mathrm{J}_{1} \mathrm{P}_{0}$ & $\begin{array}{l}29.61 \pm 0.12 \\
\mathrm{Bd}\end{array}$ & $\begin{array}{l}44.64 \pm 0.50 \\
\mathrm{Ab}\end{array}$ & $\begin{array}{l}23.25 \pm 0.37 \\
\mathrm{Bd}\end{array}$ & $\begin{array}{l}40.37 \pm 0.87 \\
\mathrm{Bc}\end{array}$ & $\begin{array}{l}28.05 \pm 0.32 \\
\mathrm{Bd}\end{array}$ & $\begin{array}{l}21.37 \pm 0.50 \\
\mathrm{Ad}\end{array}$ & $\begin{array}{l}25.25 \pm 0.69 \\
\mathrm{Bd}\end{array}$ & $\begin{array}{l}20.04 \pm 0.57 \\
\mathrm{Bc}\end{array}$ \\
\hline$J_{1} P_{1}$ & $\begin{array}{l}35.74 \pm 0.37 \\
\mathrm{Ba}\end{array}$ & $\begin{array}{l}47.01 \pm 0.24 \\
\mathrm{ABa}\end{array}$ & $\begin{array}{l}27.47 \pm 0.05 \\
\mathrm{Ba}\end{array}$ & $\begin{array}{l}43.27 \pm 0.94 \\
\mathrm{cb}\end{array}$ & $\begin{array}{l}33.05 \pm 0.75 \\
\mathrm{Aa}\end{array}$ & $\begin{array}{l}24.04 \pm 0.18 \\
\mathrm{Bb}\end{array}$ & $\begin{array}{l}30.68 \pm 0.64 \\
\mathrm{Bb}\end{array}$ & $\begin{array}{l}25.52 \pm 0.64 \\
A b\end{array}$ \\
\hline $\mathrm{J}_{1} \mathrm{P}_{2}$ & $\begin{array}{l}34.68 \pm 0.48 \\
\mathrm{Bb}\end{array}$ & $\begin{array}{l}47.64 \pm 0.29 \\
\mathrm{Ba}\end{array}$ & $\begin{array}{l}26.54 \pm 0.20 \\
\mathrm{Bb}\end{array}$ & $\begin{array}{l}50.54 \pm 0.99 \\
\mathrm{Ba}\end{array}$ & $\begin{array}{l}31.15 \pm 0.46 \\
\mathrm{Cb}\end{array}$ & $\begin{array}{l}25.52 \pm 0.55 \\
\mathrm{Aa}\end{array}$ & $\begin{array}{l}35.63 \pm 0.55 \\
\mathrm{Ba}\end{array}$ & $\begin{array}{l}29.03 \pm 0.71 \\
\mathrm{Ba}\end{array}$ \\
\hline $\mathrm{J}_{1} \mathrm{P}_{3}$ & $\begin{array}{l}31.21 \pm 0.37 \\
\text { Cc }\end{array}$ & $\begin{array}{l}44.11 \pm 0.49 \\
\mathrm{Bb}\end{array}$ & $\begin{array}{l}25.62 \pm 0.46 \\
\mathrm{BC}\end{array}$ & $\begin{array}{l}43.85 \pm 0.18 \\
\mathrm{cb}\end{array}$ & $\begin{array}{l}29.78 \pm 0.78 \\
\text { Cc }\end{array}$ & $\begin{array}{l}23.15 \pm 0.33 \\
\text { Ac }\end{array}$ & $\begin{array}{l}29.2 \pm 0.16 \\
\text { BCc }\end{array}$ & $\begin{array}{l}26.31 \pm 0.81 \\
\mathrm{Bb}\end{array}$ \\
\hline $\mathrm{J}_{2} \mathrm{P}_{0}$ & $\begin{array}{l}29.63 \pm 0.46 \\
\mathrm{BC}\end{array}$ & $\begin{array}{l}41.11 \pm 0.33 \\
\mathrm{Bd}\end{array}$ & $\begin{array}{l}22.41 \pm 0.50 \\
\mathrm{Cd}\end{array}$ & $\begin{array}{l}44.80 \pm 0.46 \\
\text { Ac }\end{array}$ & $\begin{array}{l}28.84 \pm 0.45 \\
\mathrm{Bd}\end{array}$ & $\begin{array}{l}19.83 \pm 0.09 \\
\mathrm{Bc}\end{array}$ & $\begin{array}{l}24.04 \pm 0.57 \\
\mathrm{Cb}\end{array}$ & $\begin{array}{l}18.04 \pm 0.51 \\
\mathrm{Cd}\end{array}$ \\
\hline $\mathrm{J}_{2} \mathrm{P}_{1}$ & $\begin{array}{l}35.89 \pm 0.21 \\
\mathrm{Ba}\end{array}$ & $\begin{array}{l}46.54 \pm 0.24 \\
\mathrm{Ba}\end{array}$ & $\begin{array}{l}23.67 \pm 0.48 \\
\text { Cc }\end{array}$ & $\begin{array}{l}49.38 \pm 0.40 \\
\mathrm{Ba}\end{array}$ & $\begin{array}{l}29.84 \pm 0.84 \\
\mathrm{Bc}\end{array}$ & $\begin{array}{l}24.04 \pm 0.60 \\
\mathrm{Ba}\end{array}$ & $\begin{array}{l}29.84 \pm 0.96 \\
\mathrm{Ba}\end{array}$ & $\begin{array}{l}21.30 \pm 0.57 \\
\mathrm{Bc}\end{array}$ \\
\hline $\mathrm{J}_{2} \mathrm{P}_{2}$ & $\begin{array}{l}34.26 \pm 0.18 \\
\mathrm{Bb}\end{array}$ & $\begin{array}{l}45.32 \pm 0.28 \\
\mathrm{Cb}\end{array}$ & $\begin{array}{l}25.73 \pm 0.36 \\
\mathrm{Ca}\end{array}$ & $\begin{array}{l}49.91 \pm 0.45 \\
\mathrm{Ba}\end{array}$ & $\begin{array}{l}36.05 \pm 0.33 \\
\mathrm{Ba}\end{array}$ & $\begin{array}{l}22.04 \pm 0.14 \\
\mathrm{Cb}\end{array}$ & $\begin{array}{l}30.57 \pm 0.46 \\
\mathrm{Ca}\end{array}$ & $\begin{array}{l}28.22 \pm 0.50 \\
\mathrm{Ba}\end{array}$ \\
\hline $\mathrm{J}_{2} \mathrm{P}_{3}$ & $\begin{array}{l}34.21 \pm 0.33 \\
\mathrm{Bb}\end{array}$ & $\begin{array}{l}43.74 \pm 0.32 \\
\mathrm{Bc}\end{array}$ & $\begin{array}{l}24.53 \pm 0.22 \\
\mathrm{Cb}\end{array}$ & $\begin{array}{l}46.27 \pm 0.27 \\
\mathrm{Bb}\end{array}$ & $\begin{array}{l}33.47 \pm 1.06 \\
\mathrm{Bb}\end{array}$ & $\begin{array}{l}20.20 \pm 0.42 \\
\mathrm{BC}\end{array}$ & $\begin{array}{l}29.89 \pm 0.51 \\
\mathrm{Ba}\end{array}$ & $\begin{array}{l}24.99 \pm 0.79 \\
\mathrm{Cb}\end{array}$ \\
\hline $\mathrm{J}_{3} \mathrm{P}_{0}$ & $\begin{array}{l}36.42 \pm 0.46 \\
\text { Ac }\end{array}$ & $\begin{array}{l}44.96 \pm 0.55 \\
\mathrm{Ad}\end{array}$ & $\begin{array}{l}25.89 \pm 0.43 \\
\text { AC }\end{array}$ & $\begin{array}{l}45.48 \pm 0.47 \\
\text { Ad }\end{array}$ & $\begin{array}{l}30.57 \pm 0.46 \\
\text { Ad }\end{array}$ & $\begin{array}{l}22.09 \pm 0.47 \\
\text { Ad }\end{array}$ & $\begin{array}{l}29.20 \pm 0.15 \\
A c\end{array}$ & $\begin{array}{l}23.09 \pm 0.37 \\
\text { Ad }\end{array}$ \\
\hline $\mathrm{J}_{3} \mathrm{P}_{1}$ & $\begin{array}{l}39.21 \pm 0.33 \\
\mathrm{Aa}\end{array}$ & $\begin{array}{l}47.54 \pm 0.14 \\
\text { AC }\end{array}$ & $\begin{array}{l}29.26 \pm 0.47 \\
\mathrm{Aa}\end{array}$ & $\begin{array}{l}53.23 \pm 0.32 \\
\mathrm{Ab}\end{array}$ & $\begin{array}{l}32.52 \pm 0.27 \\
\text { AC }\end{array}$ & $\begin{array}{l}30.84 \pm 0.40 \\
\mathrm{Aa}\end{array}$ & $\begin{array}{l}33.47 \pm 1.06 \\
\mathrm{Ab}\end{array}$ & $\begin{array}{l}26.10 \pm 0.6 \\
A c\end{array}$ \\
\hline $\mathrm{J}_{3} \mathrm{P}_{2}$ & $\begin{array}{l}37.47 \pm 0.52 \\
A b\end{array}$ & $\begin{array}{l}59.60 \pm 0.48 \\
\mathrm{Aa}\end{array}$ & $\begin{array}{l}27.68 \pm 0.33 \\
A b\end{array}$ & $\begin{array}{l}54.96 \pm 0.79 \\
\mathrm{Aa}\end{array}$ & $\begin{array}{l}37.20 \pm 0.55 \\
\mathrm{Aa}\end{array}$ & $\begin{array}{l}24.13 \pm 0.58 \\
\mathrm{Bb}\end{array}$ & $\begin{array}{l}39.58 \pm 1.46 \\
\mathrm{Aa}\end{array}$ & $\begin{array}{l}36.84 \pm 0.95 \\
\mathrm{Aa}\end{array}$ \\
\hline $\mathrm{J}_{3} \mathrm{P}_{3}$ & $\begin{array}{l}35.95 \pm 0.10 \\
\text { Ac }\end{array}$ & $\begin{array}{l}48.85 \pm 0.42 \\
\mathrm{Ab}\end{array}$ & $\begin{array}{l}28.05 \pm 0.14 \\
\mathrm{Ab}\end{array}$ & $\begin{array}{l}50.06 \pm 0.47 \\
\text { Ac }\end{array}$ & $\begin{array}{l}34.58 \pm 0.88 \\
A b\end{array}$ & $\begin{array}{l}23.20 \pm 1.11 \\
\text { Ac }\end{array}$ & $\begin{array}{l}32.52 \pm 0.27 \\
\mathrm{Ab}\end{array}$ & $\begin{array}{l}27.62 \pm 0.42 \\
A b\end{array}$ \\
\hline J & $\star \star$ & $\star \star$ & $\star \star$ & ** & ** & $\star \star$ & $\star \star$ & ** \\
\hline$P$ & ** & $\star \star$ & $\star \star$ & $\star \star$ & $\star *$ & $\star \star$ & $\star \star$ & $\star \star$ \\
\hline$J \times P$ & ** & $\star \star$ & $\star \star$ & ** & ** & $\star \star$ & ** & ** \\
\hline
\end{tabular}

Organic matter content of Organic matter content of rhizosphere soil in 2020 2020

Note: Different capital letters in the same column indicated significant difference in different bacteria treatments under the same phosphorus application conditions $(P<0.05)$, differences small letters in the same column mean significant difference under the 
same bacteria application conditions $(P<0.05)$.

$P_{0}, P_{1}, P_{2}$, and $P_{3}$ represent $0 \mathrm{mg} \cdot \mathrm{kg}^{-1}, 50 \mathrm{mg} \cdot \mathrm{kg}^{-1}, 100 \mathrm{mg} \cdot \mathrm{kg}^{-1}$, and $150 \mathrm{mg} \mathrm{P} \mathrm{kg}{ }^{-1}$, respectively. $\mathrm{J}_{0}, \mathrm{~J}_{1}, \mathrm{~J}_{2}$, and $\mathrm{J}_{3}$ represent $C K, \mathrm{Fm}$, $\mathrm{Bm}$, and $\mathrm{Fm} \times \mathrm{Bm}$, respectively.

Table 5 Correlation analysis of indexes of rhizosphere soil under different treatments in 2019-2020

\begin{tabular}{lllllll} 
Index & AKP & Malic acid & Oxalate & Acetic acid & Total organic acids & pH value \\
\hline Malic acid & $0.562^{\star \star}$ & & & & & \\
\hline Oxalate & $0.769^{\star *}$ & $0.579^{\star *}$ & & & & \\
\hline Acetic acid & $0.394^{\star}$ & 0.180 & $0.670^{\star *}$ & & & \\
\hline Total organic acids & $0.577^{\star \star}$ & $0.984^{\star *}$ & $0.670^{\star *}$ & 0.200 & & \\
\hline pH value & $0.627^{\star \star}$ & 0.094 & -0.620 & $0.576^{\star *}$ & 0.147 & $0.618^{\star *}$
\end{tabular}

Note $\rrbracket^{\star}$ Significant correlation was found at the 0.05 level (bilateral) $\rrbracket^{\star \star}$ significant correlation was found at the 0.01 level (bilateral).

\section{Figures}



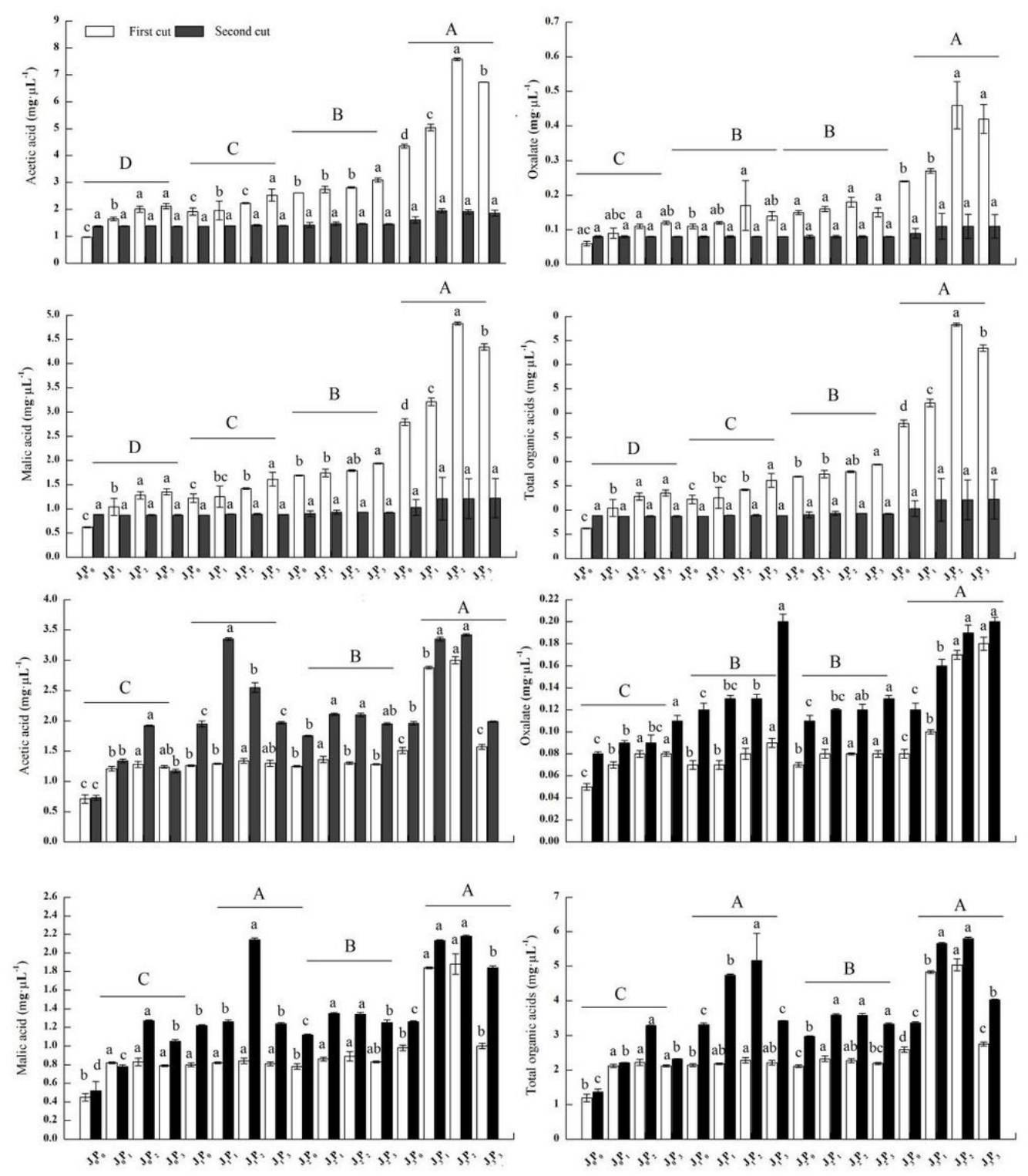

Treatments

\section{Figure 1}

Organic acid content in rhizosphere soil under different treatments in 2019-2020 Note: P0, P1, P2, and P3 represent 0 mg $\cdot k g-1,50$ $\mathrm{mg} \cdot \mathrm{kg}-1,100 \mathrm{mg} \cdot \mathrm{kg}-1$, and $150 \mathrm{mg} \mathrm{P} \mathrm{kg-1}$, respectively. J0, J1, J2, and J3 represent CK, Fm, Bm, and Fm×Bm, respectively. 


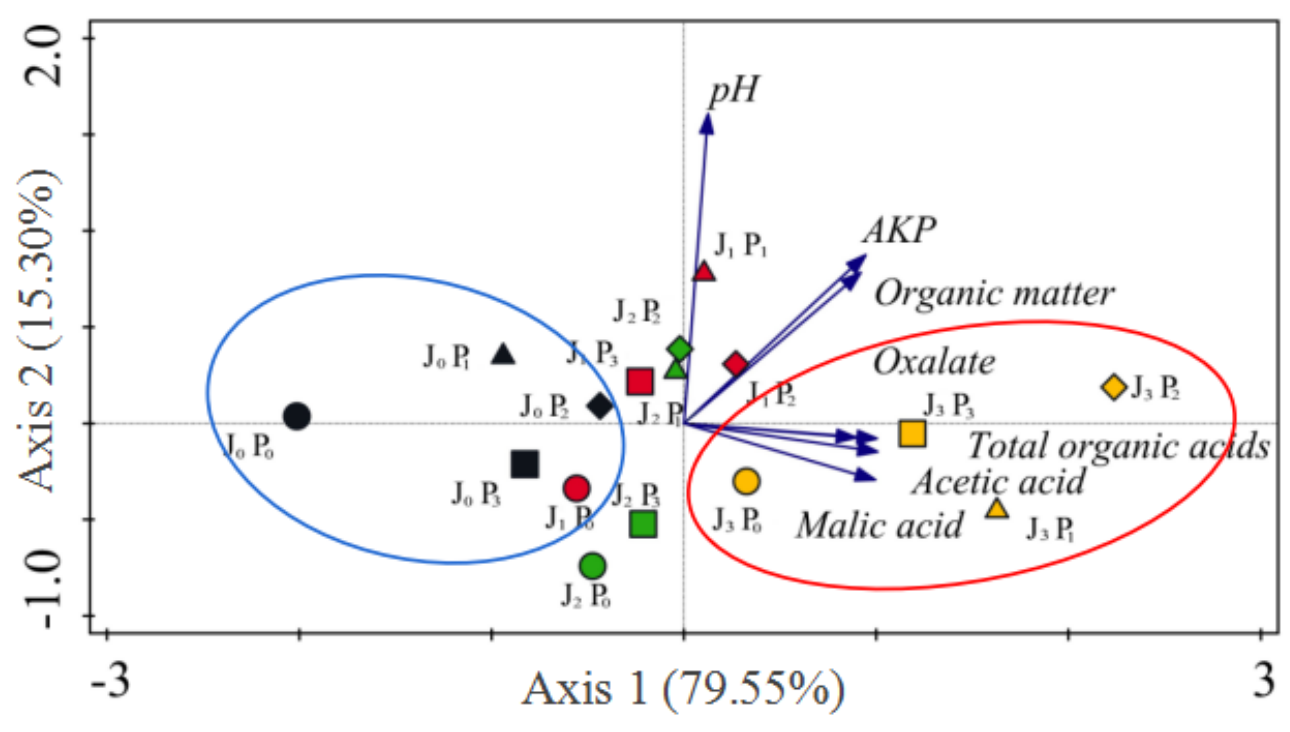

Figure 2

Principal component analysis of each index in 2019-2020 Note: P0, P1, P2, and P3 represent $0 \mathrm{mg} \cdot \mathrm{kg}-1,50 \mathrm{mg} \cdot \mathrm{kg}-1,100 \mathrm{mg} \cdot \mathrm{kg}-1$, and $150 \mathrm{mg} \mathrm{P} \mathrm{kg-1}$, respectively. J0, J1, J2, and J3 represent CK, Fm, Bm, and Fm×Bm, respectively. 